Elsevier required licence: (C) <2021>. This manuscript version is made available under the CC-BY-NCND 4.0 license http://creativecommons.org/licenses/by-nc-nd/4.0/

The definitive publisher version is available online at

[https://www.sciencedirect.com/science/article/abs/pii/S1044500521000305?via\%3Dihub] 


\title{
Beyond the decision to ally: Constraints on adapting to emergent control risks
}

\author{
Nicole Sutton $^{1 *}$ and David A. Brown ${ }^{2}$
}

Paper accepted for publication at Management Accounting Research:

\section{https://doi.org/10.1016/j.mar.2021.100756}

${ }^{1}$ Accounting, University of Technology Sydney, Australia

Email: Nicole.Sutton@uts.edu.au

${ }^{2}$ Accounting, University of Technology Sydney, Australia

Email: David.Brown@uts.edu.au

${ }^{*}$ Corresponding author at Accounting, University of Technology Sydney

PO Box 123

Broadway NSW 2007, Australia.

Email: Nicole.Sutton@uts.edu.au

Tel: +61295143285

Fax: +61295143669

\section{Acknowledgements}

We gratefully acknowledge guidance we have received from Claude Ménard, Peter Beusch, Christoph Feichter, Johnny Lind, Kalle Kraus, Frank Moers, Isabella Grabner, Alexander Brüggen, Katlijn Haesebrouck, Christoph Schneider, Niclas Hellman and Henning Christner, Lisa Jack and David Bedford; seminar participants at Maastricht University, the University of Portsmouth, Stockholm School of Economics, and UTS Business School; delegates at the $8^{\text {th }}$ Conference on Performance Measurement and Management Control (2015) and the British Accounting and Finance Association Conference (2016). We would also like to thank the editorial guidance provided by Henri Dekker and two anonymous reviewers. This paper was developed from data collected as part of a project, 'Australian cotton: Accounting for value chain sustainability and competitive advantage' (reference code: UTS1201), jointly funded by the UTS Business School and the Australian Cotton Research and Development Corporation. Our thanks extend to the project team, including Paul Brown, Hannah Pham, Kai Jin, Paul Thambar, Bruce Sutton and Dianne Hiles. 


\title{
Beyond the decision to ally: Constraints on adapting to emergent control risks
}

\author{
Abstract \\ Partners' efforts to manage risk extend far beyond decisions made when an alliance is formed \\ and continue throughout its lifecycle. As an alliance matures, it is expected that partners will \\ adapt controls to address unanticipated, emergent risks; however, empirical evidence indicates \\ that such changes are relatively rare. This study aims to advance our understanding of the \\ constraints on control adaptation by examining the role of governance inseparability, a condition \\ in which partners' prior control choices limit the range and types of subsequent strategic control \\ options. Using a longitudinal analysis of two mature alliances, we examine episodes where \\ partners struggled to switch from or differentiate alliance controls compromised by emergent \\ risks. We trace these constraints to a range of sources, including contractual commitments, \\ alliance-specific regulation, and control consistency. Furthermore, we observe how partners \\ introduced 'compensatory controls', that is, additional controls to remedy secondary control \\ problems created by the existing control infrastructure.
}

\section{Keywords:}

Alliances; risk; controls; adaptation; governance inseparability; compensatory control 


\section{Introduction}

A fundamental aspect of managing an inter-organisational alliance is ensuring governance and control strategies protect partners from exchange risks (Anderson and Dekker 2010; Williamson 1991). ${ }^{1}$ Such risks, if left unchecked, may lead an alliance to experience inefficiencies, subpar performance, or even premature termination (Anderson and Dekker 2005; Ariño and de la Torre 1998; Geyskens et al. 2006; Handley 2017; Leiblein et al. 2002; Sampson 2004). Critically, partners' efforts to manage risk extend far beyond the initial control decisions made at an alliance's formation, as controls are repaired, renegotiated, or reconfigured throughout its lifecycle (Mahama and Chua 2016; Thrane 2007; Tomkins 2001). Studies show that partners will often elaborate controls in the formative stages of alliance development as they learn about the reality of working together (Langfield-Smith 2008; Stouthuysen et al. 2019) or renegotiate contracts to rectify initial gaps or mistakes (Reuer and Ariño 2002).

As alliances mature, partners will likely encounter new risks triggered by shocks or environmental changes to the circumstances unanticipated at the time of formation. Several models of alliance dynamics that build from transaction cost economics (TCE) (Williamson 1991, 1996) predict that the emergence of unforeseen risks will require partners to revise, transition, and adapt their controls to alleviate inefficiencies and return the alliance to a state of equilibrium (Ariño and de la Torre 1998; Doz 1996; Kamminga and Van der Meer-Kooistra 2007; Kumar and Nti 1998; Ring and Van De Ven 1994; Vélez et al. 2008; Williamson 1996; Zajac and Olsen 1993). However, cross-sectional empirical studies reveal that despite the governance benefits of ex-post control adaptations, many alliances do not systematically renegotiate contracts or modify alliance controls throughout their lifespan (Ariño et al. 2008; Duplat et al. 2020; Reuer and Ariño 2002; Reuer et al. 2002). This suggests that alliance partners may be more selective in modifying control arrangements than previously thought (Duplat et al. 2020) and hints at the existence of some countervailing force constraining their strategic options to remedy emergent risks.

\footnotetext{
${ }^{1}$ In this paper we conceptualise alliances as "any voluntarily initiated cooperative agreement between firms that involves exchange, sharing, or co-development" (Gulati and Singh 1998, p.781). This extends beyond simple dyadic arrangements to include hybrids involving multiple parties, such as joint ventures, consortia and inter-firm networks (Lind and Thrane 2010; Ménard 2013).
} 
This paper aims to advance the understanding of adaptation constraints in mature alliances by examining the limits created by partners' earlier control choices. To do so, we draw on the concept of governance inseparability, “a condition in which a firm's past governance choices significantly influence the range and types of governance mechanisms that it can adopt in future periods" (Argyres and Liebeskind 1999, p.45). Governance inseparability describes how prior control choices limit firms' ability to switch between governance modes over time or differentiate the governance modes they use for alternative transactions (Argyres and Liebeskind 1999, 2002). Governance inseparability is theorised to arise from two sources: prior contractual commitments and bargaining power changes (Argyres and Liebeskind 1999). Given the poor performance outcomes of failing to adapt to changing circumstances, it would appear both variants of governance inseparability pose significant challenges in how alliance partners manage risk. However, there has been little exploration of the concept within inter-firm settings (cf. Azevedo and Silva 2007; Mayer and Argyres 2004) or its implications for interorganisational controls. ${ }^{2}$ Thus, the research aims of this study are two-fold: first, to explore how prior control choices inhibit the capacity of partners of mature alliances to switch or differentiate established controls; and second, given the potential hazards of failing to adapt, to examine how partners work within such constraints to address emergent risks.

We address these aims using an embedded longitudinal case study approach (Yin 2003) of two mature alliances used to administer large portfolios of $R \& D$ project transactions. We examine five adaptation episodes triggered by a series of significant, unanticipated disturbances in the alliances' circumstances, which exposed partners to emergent risks. We observed both forms of governance inseparability, as partners struggled to switch from or differentiate alliance controls that had become compromised by emergent problems. We also found that governance inseparability did not prevent all types of control adaptation, as partners introduced additional 'compensatory controls' to remedy the control problems created by the existing control infrastructure.

\footnotetext{
${ }^{2}$ Although there has been limited investigation of adaptation constraints within the TCE-informed interorganisational literature, accounting scholars have examined alliance dynamics, control change and inertia using a variety of other theoretical perspectives, including institutional theory, structuration theory, and actor network theory (e.g. Mahama and Chua 2016; Mouritsen and Thrane 2006; Thrane 2007; Tomkins 2001; Vélez et al. 2008).
} 
This study contributes to our understanding of how alliances manage risk over time by mobilising the concept of governance inseparability to explain how and why prior control choices constrain partners' capacity to adapt to emergent risks. In finding evidence of both switching and differentiation constraints, the study enhances our understanding of the controlrisk relation and explains why ex-post control adaptation may not be as straightforward as previously thought (Ariño et al. 2008; Duplat et al. 2020; Reuer and Ariño 2002; Reuer et al. 2002). Further, by tracing adaptation episodes, we extend the theory of governance inseparability in two respects (Argyres and Liebeskind 1999, 2002). First, we expand the explanation of its potential sources by highlighting the role of alliance-specific regulation and control consistency as further reasons why prior control choices may limit future changes. Second, we delineate the negative consequences of governance inseparability for mature collaborative arrangements, identifying how it may render them more vulnerable to exogenous shocks or limited to pursue strategic opportunities.

This study also extends our conceptual understanding of the internal relations within governance packages by demonstrating a new type of 'compensatory control' relation. By examining the dynamics between controls over time, we extend upon more static conceptualisations of the links between control elements, often represented as substitutes and complements (e.g., Duplat et al. 2020; Grabner and Moers 2013; Stouthuysen et al. 2017). Specifically, we propose that a compensatory relation emerges when one control element is used to compensate for a vulnerability created by another control. Compensatory controls thus exhibit a unique form of interdependency (cf. Grabner and Moers 2013), whereby the use of one control, attending to an original problem, gives rise to a secondary problem requiring an additional, compensatory control. Further, compensatory relations have a distinctive temporality, as they link controls introduced at different times. By capturing how partners continue to adjust and refine their governance package's control capacity, compensatory controls support the sustainability and diversity of alliance forms (Anderson and Dekker 2013; van den Bogaard and Speklé 2003).

The paper is structured as follows. Section 2 outlines the types of alliance controls partners use to manage risk and the imperatives and constraints to adapt controls over time. In Section 3, we describe our embedded longitudinal case study approach. Section 4 presents our case findings for the two R\&D alliances, describing each of the five adaptation episodes. In Section 5, we discuss 
the implications of the findings for our two research aims before placing the work in the context of future research in Section 6.

\section{Conceptual framing}

\subsection{Alliance controls}

Inter-firm alliances manage risk through a variety of structures, mechanisms and practices (Dekker 2004). This paper conceptualises the portfolio of alliance controls as comprising the hybrid governance structure, contractual agreements, partner selection strategies, and inter-firm management controls (Anderson and Dekker 2013).

The hybrid governance structure represents an alliance's overarching organisational form (Williamson 1991). More market-like hybrid structures, such as long-term supply contracts, subcontracts and licensing arrangements, exert control by engendering competition among suppliers and enforcing provisions in the contract (Gulati and Singh 1998; Ménard 2013). More hierarchical hybrid structures, such as joint ventures and strategic alliances, control by pooling equity, often via a central entity (Pisano 1989; Sampson 2004).

Contractual agreements safeguard transactions by specifying the terms and conditions of exchange and providing legal recourse for any violations (Anderson and Dekker 2010). While a contract may stipulate the terms of the transaction, they often also include provisions specifying how the alliance should operate, such as the allocation of responsibilities, the division of income and the resolution of disputes (Anderson and Dekker 2005; Ding et al. 2013; Reuer and Ariño 2007).

Partner search and selection processes mitigate risk by considering the alliance counterparts (Reusen and Stouthuysen 2020; Van der Meer-Kooistra and Vosselman 2000). Alliance members may invest more effort to identify a suitable partner, emphasise specific selection criteria, or select counterparts with prior ties (Dekker 2008; Dekker and Van den Abbeele 2010; Ding et al. 2013; Li et al. 2008).

Inter-firm management controls include outcome, behaviour, and social controls (Dekker 2004; Langfield-Smith and Smith 2003). Outcome controls specify, monitor and reward partners for achieving desired results (Neumann 2010; Speklé 2001). Behaviour controls, such as joint 
planning, rules, or supervision, ensure partners undertake agreed upon activities (Anderson et al. 2017; Johansson and Siverbo 2011). Social controls induce cooperative behaviour through relational practices that foster and align partners' values, attitudes and competencies (Dekker 2004; Langfield-Smith and Smith 2003; Phua et al. 2011).

In recognising that alliances rely on combinations of controls, inter-firm scholars have pursued two lines of inquiry. First, they have sought to characterise the overall 'governance package' (Caglio and Ditillo 2008; Johansson and Siverbo 2011). For instance, a popular typology characterises control combinations in terms of their dominant pattern, contrasting market-based, bureaucracy-based, and trust-based control patterns (Van der Meer-Kooistra and Vosselman 2000). Second, scholars have investigated the types of relations that exist between controls. As in intra-firm research, the most common way of conceiving these linkages has been through the dichotomy of 'substitute' and 'complementary' relations (Anderson and Dekker 2010; Bedford et al. 2016; Grabner and Moers 2013). A substitute relation is said to exist when the use of one control reduces the need for the other, whereas a complementary relation occurs when the use of one control enhances or facilitates the use of the other (Duplat et al. 2020; Poppo and Zenger 2002; Stouthuysen et al. 2017). Several studies, for example, examine whether partner selection has a complementary or substitutive effect on other controls (Dekker 2008; Dekker and Van den Abbeele 2010; Li et al. 2008); however, they often reveal hidden complexity in these associations. For instance, having prior experience with a partner is found to lessen the need for search processes, yet also appears to facilitate the design of more extensive management controls (Dekker and Van den Abbeele 2010). A suggested form of inquiry is to study these relations longitudinally (Tomkins 2001), as has been fruitfully employed in studies unpacking the dynamic interplay between trust and formal controls over time (Huber et al. 2013; LangfieldSmith 2008; Mahama and Chua 2016; Vélez et al. 2008).

\subsection{Alliance controls and risk}

Inter-firm transactions expose partners to a host of risks, including the appropriation of shared assets, coordination failures and opportunistic behaviour (Anderson et al. 2014; Caglio and Ditillo 2008; Das and Teng 1996). As these hazards can undermine alliance effectiveness (Anderson and Dekker 2005; Ariño and de la Torre 1998; Geyskens et al. 2006; Handley 2017; Leiblein et al. 2002; Sampson 2004), a critical aspect of alliance management is ensuring 
appropriate controls to safeguard, mitigate or redress risk. The most common way of conceiving the relation between alliance controls and risk is through the lens of TCE (Anderson and Dekker 2013). Fundamentally, TCE predicts an efficient alignment between the riskiness of transactions and types of governance (Williamson 1991). As Macher and Richman (2008, p. 5) explain:

\section{To use a simple mode of governance to manage a complex transaction would be to risk contractual breakdown, whereas to use a complex mode of governance to manage a simple transaction would be to incur additional costs without significant gain.}

To date, most inter-firm control research has used TCE to investigate how alliance controls align to the ex-ante properties of the exchange, including the transaction, parties, or environment (e.g., Anderson and Dekker 2005; Anderson et al. 2000; Dekker 2004, 2008; Dekker and Van den Abbeele 2010; Ding et al. 2013; Donada and Nogatchewsky 2006; Langfield-Smith and Smith 2003; Neumann 2010). These properties, such as the specificity of partners' investments or the length of their previous collaborations, are theorised to influence the propensity for future hazards, and as a consequence, the partners' initial choice of the alliance controls (Speklé 2001; Van der Meer-Kooistra and Vosselman 2000). ${ }^{3}$

An extension of this approach tempers the assumption that partners with foreseeable foresight will know future hazards by emphasising their bounded rationality when establishing the alliance (Williamson 1996). This view suggests that partners only understand the true extent of risk once the alliance is operational (Ariño and de la Torre 1998; Mouritsen et al. 2001; Stouthuysen et al. 2019). Control implementation is seen as a protracted process involving successive decisions about the structure, partners, contract and management controls (Dekker and Van den Abbeele 2010). Alliance controls develop over time, as partners learn to trust each other, performance expectations are clarified, or controls are elaborated upon (Ariño et al. 2008; Langfield-Smith 2008; Langfield-Smith and Smith 2003; Mahama and Chua 2016; Mouritsen and Thrane 2006; Reuer et al. 2002; Stouthuysen et al. 2019; Thrane 2007). ${ }^{4}$

\footnotetext{
${ }^{3}$ This argument builds directly from TCE's 'make or buy' decision, which models the choice of governance structure on the likely severity of contracting hazards, as determined by the transaction's ex-ante characteristics (Williamson 1998).

${ }^{4}$ This type of learning to control within a single exchange differs from the 'learning to contract' that accumulates during successive exchanges (e.g. Mayer and Argyres 2004).
} 
A final stream examines post-formation changes made to rectify mistakes in the initial choice of controls. Studies investigate the implications of ex-ante 'misalignment', whereby managerial error or hubris causes the initial controls to be either excessive or inadequate to manage risk (Ariño et al. 2008; Johansson and Siverbo 2011; Sampson 2004). This work leverages TCE's discriminating alignment assumption. While controls and risk may momentarily exist in states of disequilibrium, competitive pressures will push partners to select controls that provide appropriate safeguarding at the lowest cost (Williamson 1996). Researchers using retrospective surveys find that initial control misalignment prompts subsequent changes in governance mechanisms and contractual renegotiation (Ariño et al. 2008; Reuer and Ariño 2002; Reuer et al. 2002).

In sum, existing explanations about the relation between alliance controls and risk focus on partners' efforts to establish adequate controls in the alliance set-up; develop controls as they come to understand the hazards over time; or reconfigure controls to rectify initial mistakes. Although the latter two explanations involve ex-post changes to alliance controls, these are explained mainly in terms of ex-ante conditions. Thus, what remains underdeveloped is an understanding of how controls within more established ventures are used to manage more emergent risks.

Conceptual models of alliance dynamics often differentiate between the initial negotiation and execution phases, and subsequent phases when controls are re-evaluated, renegotiated and reconfigured (Doz 1996; Kumar and Nti 1998; Ring and Van De Ven 1994; Zajac and Olsen 1993). These models suggest that adjustments are often triggered by external disturbances or contingencies, such as environmental shocks or shifts in partners' strategies, which disrupt the efficient equilibrium of controls (Ariño and de la Torre 1998). Critically, if these contingencies are unanticipated, their occurrence will expose partners to risks for which the existing control infrastructure is inadequate. Thus, partners are expected to adapt their controls or otherwise bear the performance penalties of misalignment (Ariño et al. 2008; Duplat et al. 2020; Reuer and Ariño 2002; Stouthuysen et al. 2019).

Although there are many longitudinal accounts of changes within inter-firm controls (e.g., Mahama and Chua 2016; Mouritsen and Thrane 2006; Stouthuysen et al. 2019; Thrane 2007), studies of mature alliances are comparatively rare. Kamminga and Van der Meer-Kooistra 
(2007) observe a transition in control patterns triggered by a regulatory change. The new regulation altered the conditions of the joint venture and "increased the appeal" of more intense forms of control. Vélez et al. (2008) observe how joint activities' expanded scope and complexity, increased partner interdependence, and prompted further elaboration of controls. Although neither study explicitly considered ex-post risk per se, their observations are generally consistent with a pattern of control adaptation in response to emergent risk.

\subsection{Constraints on adaptation}

Despite the imperatives for adapting alliance controls, it may not always be straightforward to do so. Studies of post-formation changes reveal that firms are selective in renegotiating alliance controls. For example, surveys by Reuer and Ariño (2002), Ariño et al. (2008) and Duplat et al. (2020) find that only a minority of alliances renegotiate their contracts $(20 \%, 22 \%$ and $36 \%$ of their samples, respectively). Furthermore, Reuer et al. (2002) find that less than half (44\%) had experienced any change in either their contractual agreements, joint board, or monitoring mechanisms, meaning that the majority of alliances experienced no change in their governance mechanisms at all.

Also, when studies model the effect of ex-post disturbances, they find weak or inconsistent relations with post-formation governance changes. Both Ariño et al. (2008) and Reuer and Ariño (2002) find that contractual renegotiations are more likely after shifts in strategy, but not after environmental changes. Reuer et al. (2002) find that expanding the alliance's scope is related to increased monitoring mechanisms but has no effect on the joint board or contract. Duplat et al. (2020) find that neither environmental uncertainty nor change in joint venture scope influence contractual renegotiation. These results could be interpreted as refuting the notion that firms need to adapt their alliance controls when ex-post disturbances occur (e.g., Ariño and de la Torre 1998). However, an alternative explanation is that despite the need to adapt, alliance partners are unable or unwilling to do so. ${ }^{5}$ Duplat et al. (2020) propose that the selectivity of contractual

\footnotetext{
${ }^{5}$ There are two further possible explanations for these inconsistencies, which we address in our research design. The first, as mobilised in Duplat et al. (2020), is that the need to adapt one type of control (i.e. contractual renegotiation) may be attenuated by the existence of another (i.e. relational governance). This points to the importance of considering the adaptation that may occur across an alliance's entire portfolio of controls, i.e. an entire 'governance package'. The second is that statistical associations may be weakened by temporal lags that can occur in alliance
} 
changes likely reflect partners' trade-offs of the expected governance benefits against the nontrivial costs of renegotiating. However, to clarify which explanation holds requires closer empirical investigation of the ex-post adequacy of controls and further theoretical consideration of the possible constraints limiting partners' ability to adapt.

Within the inter-firm control literature, the issue of adaptation constraints has been largely overlooked. An exception is Phua et al. (2011), who conceptualise the switching costs arising from initial control choices, which create exit barriers to outsourcing arrangements. Building from Williamson (1996; 1998), they argue that firms make investments in controls (Anderson and Dekker 2005) which they are reluctant to abandon and replace. While their field study concerns the implications of initial control investments on the ease of switching suppliers (rather than on the ease of changing controls), they provide qualitative evidence substantiating the cost of control as a potential constraint of future control choices.

We seek to advance the understanding of the constraints on control adaptation by drawing on the concept of governance inseparability. Governance inseparability was first developed by Argyres and Liebeskind (1999, p. 50) as a condition where partners "may be constrained in their choice of mechanisms because of past governance choices". The concept was formulated to expand TCE's focus on individual transactions isolated in time by recognising that a firm's past governance choices reduce the range of governance mechanisms it can adopt for subsequent and different transactions (Argyres and Liebeskind 2002).

Argyres and Liebeskind (1999) propose that governance inseparability can reduce the range of future control choices in two ways, both of which appear relevant to established alliances. First, when firms have a history of governing a given transaction in a certain way, this can limit their ability to switch to another control mode, even if the underlying conditions of the transaction change. If adaptation imposes too high a switching cost, partners may opt to continue to use alliance controls that are not necessarily optimal for that particular transaction (Williamson 1996). As Leiblein and Miller (2003, p. 842) explain:

adaptation processes (Mayer and Argyres 2004; Stouthuysen et al. 2019), which may be better studied longitudinally. 
While much of the existing TCE literature assumes that firms may effortlessly renegotiate existing contractual provisions as they adapt to changing exchange conditions, the existence of an extant governance form is likely to create switching costs that may lock a firm into a particular governance choice.

Second, when firms have one governance arrangement in place for one transaction, they may be obligated to adopt that same arrangement for another - even if it is inefficient (Argyres and Liebeskind 1999). Thus, partners face constraints in their ability to differentiate their governance arrangement across multiple transactions. Differentiation constraints could limit segmentation strategies, where firms adopt different controls for different suppliers (Gietzmann and Larsen 1998). They may also occur when a single alliance structure is used to administer multiple exchanges, as the controls used for one transaction shape the controls used for another.

Governance inseparability conceives constraints through the logic of costs, whereby the limits on switching or differentiation occur because the benefits of doing so are outweighed by the cost (Argyres and Liebeskind 1999). These costs may include legal liabilities for contractual breaches; the time, effort and inducements required to renegotiate; or the political and social costs associated with terminating or restructuring inefficient operations (Argyres and Liebeskind 1999; Leiblein and Miller 2003; Williamson 1998). Argyres and Liebeskind (1999) identify two potential sources of governance inseparability. The first is prior contractual commitments, which may explicitly preclude a partner's ability to either alter the governance of the arrangement (or make such alterations prohibitively costly) or enter into a different arrangement with another provider. The second is a change in relative bargaining power, in that a partner may be forced to continue with a particular governance mode or be precluded from entering into other agreements by a powerful trading counterpart.

In describing how past control choices may limit partners' strategic options, governance inseparability articulates the complexity of adapting an established alliance, distinct from creating one anew (Ariño and de la Torre 1998; Doz 1996). In particular, Argyres and Liebeskind (1999) identify its relevance in explaining organisational inertia (Sydow et al. 2009). Contractual commitments may lock partners into a set of controls, thus preventing future adjustments to more efficient modes of governance and restricting a firm's ability to adapt to changes in circumstances (Argyres and Liebeskind 1999; Leiblein 2003). Thus, governance 
inseparability theorises a weak-form path dependency, in which history does not necessarily generate inefficiencies but instead creates conditions that are too costly to reverse (Azevedo and Silva 2007; Liebowitz and Margolis 1995). Most empirical research on governance inseparability has focused on industry-level effects, such as competition, evolution and firm variation, rather than on its micro-level implications for adaptation within individual arrangements (Argyres and Liebeskind 2002; Leiblein and Miller 2003). This study, therefore, explores how governance inseparability inhibits the capacity of partners to switch or differentiate established alliance controls. Further, given the apparent imperative to adapt alliance controls, this study explores how partners work within such constraints to address emergent risks.

\section{Method}

To address these two aims, we used an embedded longitudinal case study design (Yin 2003), examining five episodes of adaptation within two mature R\&D alliances in the Australian cotton industry. Using a qualitative approach enabled us to study alliance risks as perceived by partners rather than relying on statistical risk proxies (Anderson et al. 2014). In addition, similar to Doz (1996), our longitudinal design enabled us to examine individual episodes of adaptation within the two cases. Critically, this episodic analysis allowed us to observe the temporal dynamics between our central theoretical constructs over time (Langfield-Smith 2008; Langfield-Smith and Smith 2003; Stouthuysen et al. 2019), such as the emergence of new risks, the sources and types of governance inseparability, and the subsequent control responses of alliance partners.

\subsection{Case sites}

The two case sites are the Cotton Research and Development Corporation ('CRDC') and the Cotton Cooperative Research Centre ('Cotton CRC'), both established by legislation by the Australian Government in the early 1990s (see Table 1). Our study's focal period from 2007 until 2014 corresponds to their mature or stable phase (Tomkins 2001). ${ }^{6}$ Both cases are multitransactional alliances, established to contract and administer several hundred R\&D projects per year on behalf of various funders (e.g., government, industry organisations, commercial firms). Due to their 'low contractibility' (Johansson and Siverbo 2011), these R\&D projects were often

\footnotetext{
${ }^{6} \mathrm{We}$ also focused on this period as it overlapped with the time we were in the field, and leveraged participants' recollections of the more recent past (Vélez et al. 2008).
} 
highly prone to contracting hazards (Gulati and Singh 1998; Oxley 1997; Sampson 2004). Also, despite several similarities, the CRDC and Cotton CRC were established under different legislation, thus creating differences in their operating contexts and alliance controls. ${ }^{7}$

$<$ INSERT TABLE 1 ABOUT HERE $>$

\subsection{Data collection}

The study's empirical material was collected as part of a larger project on the Australian cotton industry. Fieldwork was conducted between June 2012 and March 2014, during which we conducted 11 field trips (see Table 2). This prolonged period of fieldwork allowed us to gain an understanding of R\&D's role in the industry, become familiar with alliance members, and observe the interactions between different alliance partners.

\section{$<$ INSERT TABLE 2 HERE $>$}

During our fieldwork, we conducted 64 face-to-face interviews (listed in Table 3). These semistructured interviews allowed us to gather accounts from individuals from various partner organisations involved in the two alliances.

\section{$<$ INSERT TABLE 3 HERE $>$}

Finally, we collated archival documentation relating to the period 1990-2014 to trace the evolution of both alliances and verify interviewees' accounts, particularly their recollections of events that predated our entry into the field. We examined alliances' annual reports, long-term strategic plans, and annual operating plans, and extracted annual data about alliances' revenue and expenditure on $R \& D$ and details about open projects. The archival material also helped us trace significant changes in the alliances' environment and strategies, and the evolution of their management structures, corporate governance, and management approaches. We also collected artefacts representing the alliance controls, such as relevant government legislation and governance documents; copies of contracts and deeds; project management policies and

\footnotetext{
${ }^{7}$ As well as operating in the same industry, both the Cotton CRC and CRDC were headquartered near Narrabri, one of the main cotton growing regions in Australia and home to the Australian Cotton Research Institute (ACRI), which houses $60-80$ cotton scientists from national and state public agencies.
} 
procedures; and individual project documentation, such as proposals, progress reports, financial reports and evaluations.

\subsection{Data analysis}

We used a systematic coding and qualitative analysis process to interpret our empirical material (Eisenhardt and Graebner 2007; Yin 2003). We first developed a general understanding of the two cases' controls at the start of our study period in 2007 (see Table 4). The alliances' controls comprise all the mechanisms used to administer the transaction between the funders (e.g., government, industry) and researchers (e.g., scientists), including the structure of the alliance itself, contracts, partner selection and inter-firm management controls relating to the R\&D projects. We excluded from the analysis the internal controls used to manage alliance operations and staff (e.g., the budget used to control the administrative expenditure of the central entities).

We then focused our analysis on five identifiable episodes of adaptation within the two cases. These were situations where partners described the emergence of a problem that required a response. Like other studies of alliance dynamics, the choice of using an episode as the unit of analysis "allow[ed] us to trace the interactions between the partners in response to specific stimuli" (Ariño and de la Torre 1998, p. 309, see also Mouritsen et al. 2001; Vélez et al. 2008). For each episode, we collated coded material to understand the nature of the emergent risk, constraints on partners' control choices, and alliance partners' responses. ${ }^{8}$ We then used the empirical material to construct chronological episode narratives to understand the temporal patterns within the control adaptation process, which often spanned multiple years.

The cross-case analysis then involved a 'pattern-matching' process, comparing the adaptation process across the five episodes and relating those patterns to the prior literature (Eisenhardt 1989; Yin 2003). To structure this analysis, we constructed data matrices (Miles et al. 2014; Saldaña 2013), summarising the evidence in each episode by theoretical construct. A final version of this matrix is presented in Table 5. The temporal sequence within each episode can be inferred by looking across the rows; this identifies the emergence of risk (including the underlying trigger or disturbance, the nature and scope of risk), the constraint created by

\footnotetext{
${ }^{8}$ To identify and sort this material, we combined conventional content-based codes (e.g. 'contractual agreement'), with 'scope codes', which classified interviewee comments as referring to the industry, alliance, program or transactional-level (Saldana 2013).
} 
governance inseparability (including the nature and source of the constraint), and partners' subsequent control responses to resolve the emergent risk (including the changes to the contract, partner search and selection, and inter-firm controls). The between-episode similarities and differences for each construct can be inferred by looking down the columns. This step was helpful, for example, in identifying the alternative sources of governance inseparability and the types of controls that were changed more often. Like Doz (1996), we then compared the episodes on a pattern- rather than construct-level. For example, we looked for similarities in the risk context and control changes when partners confronted differentiation constraints (e.g. Episodes 3 and 4) or differences between the control changes across episodes occurring within the same case alliance (e.g. Episodes 1 to 3). Finally, we compared the cross-case patterns with the prior literature to develop theoretical insights (Eisenhardt 1989), specifically about how and why different forms of governance inseparability emerge in mature alliances and the implications each has for how partners attempt to manage emergent risk.

In Section 4, for each alliance, we first outline the established controls as they were in 2007 , followed by a chronological account of each adaptation episode. In Section 5, we then integrate relevant insights from the cross-case analysis to explicate the theoretical implications of the case findings in addressing our two study aims.

\section{Case findings}

\subsection{Cotton Research and Development Corporation}

The CRDC was first established in 1990 to invest in research on behalf of the Australian Government and cotton growers. It was one of 15 Rural Development Corporations established under the Primary Industries and Energy Research and Development Act 1989 (Cth) ('PIERD Act'). The legislation structured the CRDC as a competitive subcontracting alliance, with a central entity administered by a Board of Directors and supported by internal managers. The PIERD Act also established the CRDC's revenue, set as a mandatory industry R\&D levy matched by the government. ${ }^{9}$ These funds were invested in a portfolio of R\&D projects

\footnotetext{
${ }^{9}$ Each year Australian cotton farmers paid $\$ 2.25$ per bale of cotton produced to the CRDC, which was matched by the government.
} 
conducted by researchers employed at public science and agricultural agencies, universities and private consultancies.

\section{$<$ INSERT FIGURE 1 HERE $>$}

The alliance was formalised through two sets of contracts, mediated by the CRDC entity (see Figure 1). The first was a long-term Deed Agreement ('Deed'), based on the PIERD Act, between the Board and the funders (Cotton Australia, the peak industry body, and the Australian Department of Agriculture). The Deed committed funders to contribute resources in perpetuity, gave funders oversight of the CRDC Board, and required the Board to submit five-year strategic plans, annual operating plans, annual reports, and quarterly financial reports. The second set of contracts were project-level agreements with researchers, which specified the terms of exchange for each project, including the dollar investment, milestones and outcomes, project design and personnel, and intellectual property. The CRDC intentionally limited the scope of R\&D projects by disaggregating larger initiatives into multiple contracts. It tended to contract with individuals rather than larger teams, and funded long-term research programs through recurrent short-term contracts. For example, an annual survey of "Diseases in Cotton" had run continuously since 1995, funded by six consecutive three-year contracts. Restricting project scope allowed the CRDC to increase researcher competition and accountability, and create contract renewal incentives.

Most research projects were initiated through an annual competitive funding process where researchers proposed projects to address strategic priorities. Funded projects were organised into program areas and monitored by program managers using bi-annual progress reports, periodic financial reports, and final project reports tied to milestone payments.

\subsubsection{Episode 1: Inexperienced R\&D investment decision-makers}

Historically the CRDC Board - the key decision-making body of the alliance - comprised representatives from cotton growers, government and research agencies. However, following a government inquiry into representative boards (Uhrig 2003), the PIERD Act was amended in 2007 to require the Board's composition to be 'skills-based'. By 2008, more than half the CRDC's non-executive directors had no direct experience in the cotton industry: 
So, the CRDC Board in the past were often quite hands on, and the government has said, no, we want skills-based boards. These people were flying in from all over the countryside for a board meeting and then going again ... That can be dangerous, depending on that person. (Researcher A)

This situation was considered "dangerous" because the Board was responsible for making investment decisions about which R\&D projects to contract as part of the annual planning process. Such decisions were often highly complex, involving trade-offs between long-term technology options. In this context, the Board's lack of cotton industry-specific experience put the alliance at risk of making poor R\&D project selection decisions. This risk could have been ameliorated by decentralising the CRDC's investment decision-making function to its more knowledgeable and experienced program managers. However, Section 26 of the PIERD Act and the CRDC's Deed explicitly required the Board to make all investment decisions (CRDC Deed). In 2009, coinciding with the change in the Board composition, the CRDC established dedicated grower advisory panels to "consider relevant research applications in detail and report their views to the organisation as a whole at the annual research review meeting" (CRDC Annual Report 2010, p.38). Although the Board retained the final investment decision, the grower panels provided them with advice:

At the end of the day, the Board of the R\&D corporation makes the decision, but they place a lot of weight on what the farmers want. (Cotton Australia Manager A)

The panels compensated for the Board's lack of industry knowledge by providing rankings and feedback on project proposals about their strategic importance, researcher reputation, feasibility, and relevance of the proposed project:

The growers do a really good job of helping us get the scale of an issue and help us to try and understand, well, yes, that's a really big issue, and actually, we do end up with four or five projects across that issue...It might be a one in 10-year issue and [the panel] remind you that it was around 10 years before your time, it never turned into this big, hairy monster. (CRDC Manager A)

At the same time, the CRDC also increased the intensity of screening and evaluation processes by the program managers. The program manager evaluations of project proposals, which fed into 
the Board's decision-making, became much more standardised, formalised and detailed (CRDC Manager A). They completed standardised evaluation reports describing each project's strategic alignment, methodology, expected financial returns, researcher capability, likelihood of completion, project ranking, and spider graphs depicting the project value against several criteria.

In summary, this episode reveals how a risk emerged due to a regulatory change, which compromised the alliance's central investment decision-making function. As the alliance's legislated structure constrained the ability to decentralise these decisions, the risk was instead mitigated by introducing additional project evaluation processes, which the Board used to inform their investment decisions.

\subsubsection{Episode 2: Tensions with research providers}

The CRDC's revenue stream is highly variable, changing with the annual level of cotton production. Further, as production relies on rainfall, the CRDC's funding has become increasingly exposed to climate volatility. Figure 2 shows the variable annual rainfall patterns in the Murray Darling Basin, Australia's primary cotton region (the vertical bars). During the CRDC's first decade, the even climate conditions (oscillating between years of 'positive' and 'negative' rainfall variances) created steady growth in revenue and the number of R\&D projects. However, a severe drought between 2000 and 2008 caused a substantial contraction in the CRDC's annual revenue, from a peak of $\$ 16.2 \mathrm{~m}$ in 2003 to $\$ 7.0 \mathrm{~m}$ by 2008 . The CRDC initially buffered this revenue loss by drawing on reserves, before then cutting expenditure and reducing the size of its R\&D portfolio.

\section{$<$ INSERT FIGURE 2 HERE $>$}

Although the CRDC's competitive subcontracting model, with short-term project contracts and annual funding rounds, was well-suited to managing variations in revenue during the drought, it became a source of contention with research providers once the rain returned. As one scientist explained:

So that three-year cycle and instability that goes along with that is probably, I think, the biggest challenge and weakness, and we lose good people. We had a microbiologist who was here, and 
he loved it here, and there was no funding in the drought. There was no funding to keep him on here, so he's moved back overseas, and people are saying, 'we really could do with some soil microbiologist here'. Okay... we had one. (Researcher B)

The prolonged drought exposed a latent tension about how the CRDC alliance contracted R\&D projects requiring specific scientific expertise. CRDC-funded scientists made lengthy educational investments in Australian cotton science and incurred personal costs to relocate to regional research sites. While the annual variability of funds had always posed a risk, the increased volatility heightened their concerns:

I know that I need people here that are thinking beyond the three-year project, and then they're faced with the funding cycle all the time. It's just really hard... It's hard on the individuals and hard on the people who have to tell them they don't have jobs all the time. (Researcher C)

As a result, post-drought, the CRDC encountered significant difficulties in negotiating with researchers, who were unhappy about the arm's length subcontracting nature of the alliance, the short funding cycles and their perceived role as 'external' contractors:

As far as I'm concerned, a successful industry would be one where that was something that was done as a collaborative partnership...It has been evolving and has got to a point where it has become the opposite of all of those things, sort of dictatorships and things imposed upon you. 'No, we're not going to fund that' - those sorts of things - without discussing them before the point a decision is reached. (Researcher A)

The CRDC is bound by the PIERD Act, which stipulates the funding structure and the centralised model of investment decision-making (Section 30, PIERD Act). Furthermore, the Deed explicitly stipulated that the CRDC was not obliged to provide funding to a specific provider and had sole discretion to allocate funding to other providers (CRDC Deed). The CRDC managers were also reluctant to abandon the alliance's industry-oriented strategic plan and shortterm, competitive procurement of $R \& D$ :

It's much more reflective of what [the] PIERD Act is designed to do. We're not here to support the notion that we maintain the livelihood of researchers. It's the other way around. Researchers sustain the livelihood of growers. End of story. (CRDC Manager B) 
However, the CRDC managers were willing to adjust several other alliance mechanisms that influenced the project selection. The five-year strategic plan was modified, shifting from six tightly defined research areas into three broad programs to create more opportunity for researchers to be eligible for funding ('Planning assumptions', Strategic R\&D Plan 2008-2013). Also, at least half of the 2008 Strategic R\&D Plan was developed from areas of existing investment to support continuity in research funding:

We're not the Titanic, we're not that big that we can't turn, but it does take a year-it does take a couple of years to change direction in a sensible way without it impacting on people's livelihoods and careers. You don't want to be insensitive to that sort of stuff. (CRDC Manager C)

The annual project selection process was also modified to reduce the initial workload of researchers in applying for funding. A shorter preliminary proposal stage was added, with only successful applicants required to submit a full 30-page final proposal. Although the additional stage increased the workload of the program managers, it created an opportunity for projects to be negotiated over successive rounds:

So once the Board has approved the project, they might put certain conditions on it and might say we need to reduce the budget by X per cent. You then have to work directly with those research providers to negotiate and hopefully agree that a research proposal meets the [research] provider's needs, what they think is important, and what the Board has set as the parameters. (CRDC Manager D)

This second episode shows how increased revenue volatility exposed a latent source of tension with $R \& D$ providers given the short-term R\&D funding model and the high asset specificity of the workforce. As the CRDC managers could not alter their funding model, they instead modified the strategic planning and project selection processes to be more flexible and accommodating to researchers.

\subsubsection{Episode 3: Mutual dependence on 'core' providers}

When the CRDC had a smaller R\&D budget due to reduced revenue, it prioritised specific projects, such as long-term surveys of soil conditions and diseases, or initiatives that maintained cotton's genetic protection against pests. The scientists conducting these 'core' projects were highly valued for their expertise, relational ties within the industry, and access to specialised 
equipment and facilities. Also, those who conducted annual surveys had a unique knowledge of the collection protocols, which was crucial to ensuring the continuous accumulation of comparable year-on-year data. While the preservation of core researchers was logical, these researchers became increasingly dependent upon CRDC funding:

So in the mid-2000s, particularly when that drought got to be pretty bad, the funding became quite constrained - industry funding - and the research organisations becoming more and more reliant upon that. (Researcher $A$ )

The core scientists also became increasingly difficult to replace, as the cuts disrupted long-term succession planning:

But when you go into that sort of prolonged drought, five years, we had to reduce expenditure by 25 per cent, not only external funding but our own costs... It's all about what's core... we've got to keep that and the pain is that you lose any ability to do succession planning. (CRDC Manager D)

The increased mutual dependency between the CRDC and core scientists created new concerns about their relationship. For example, researchers felt beholden because they relied on the CRDC funding to continue their work:

The reality is that whilst we get resources over here [Provider's own $R \& D$ funding], we need the resources from over here [CRDC funding], and if we don't have both, nothing happens, and that's where the tension comes in. So, you become almost answerable to this because-and they've got that leverage because they know without them, this doesn't exist, it disappears (Researcher C)

Correspondingly, the CRDC managers felt researchers were using their position to demand more favourable terms:

We do have some projects that have been reasonably long-term, looking at now maybe the start of the third project in a particular area. It becomes really challenging when we see just suddenly the total budget doesn't change, but our contribution to it jumps by 20 to 40 per cent...No consultation, it just comes in the budget. (CRDC Manager E) 
It appears both parties' cynicism manifested around the others' financial contribution. This tension was seen as a significant threat to their future contracts:

If you extrapolate from where we used to be with the relationship between CRDC and research providers, where we are today and where we'll be in that same amount of time, we'll be at war. That's a frightening thing. I don't know - our boss has been trying to negotiate a compromise in terms of all this funding issue with - and they're not getting anywhere. Just not getting there at all. (Research Provider A)

Again, the CRDC subcontracting model appeared under strain, undermined by the mutual dependency on core researchers due to drought-induced cuts. The CRDC managers described the diversity of researchers' needs across their portfolio:

You do feel like sometimes you've got all these different cats, and the sand starts to shift around them depending on what's going on broadly and then you're trying to juggle all of those balls (CRDC Manager F)

Managers struggled to address individual researchers' unique needs. They were constrained by funding and operating rules, which specified standardised timelines and detailed application processes for all projects in its portfolio, including "the 10 steps for cotton industry R\&D investment grant funding” (CRDC Researchers Handbook 2012-13, p.13). While CRDC managers were "very conscious of the fact that you do make decisions about investments that affect people's lives", they needed to "approach [their] job with a very heavy sense of fairness, of trying to be brokers of fair" (CRDC Manager A).

We observed the first preliminary adaptations of the CRDC's alliance controls attempting to balance this tension during the fieldwork period. We observed that core research providers' projects were often given high rankings during the proposal review process, as panellists and program managers weighted reputation in their assessments. Also, the CRDC altered the proposal process for core providers to signal they were "highly valued to the industry" (Cotton Australia Manager B). Some researchers were offered commissioned projects outside of the annual funding cycle, while others were invited to fast-track through the application. Finally and perhaps most radically, the CRDC was considering providing contracts of longer duration: 
One of the things we are starting to look at doing is identifying those core projects which we see as ones that are really important, because it does give us that ongoing knowledge and capacity. So, we're looking to start funding those for five years, rather than three, so they don't get treated in the same way. (CRDC Manager F)

Extending the contract duration was a significant departure from the CRDC's traditional contracting process. Offering these terms was intended to reduce uncertainty for researchers, reduce the risk and cost of applying for funding, and reduce key personnel's loss.

In summary, the need for adaption emerged from an increased mutual dependency between the CRDC and core researchers. This mutual dependency sat awkwardly with the competitive subcontracting structure, leading to scepticism among the parties. Although the need for consistent procurement rules limited their strategic options, managers worked within these rules to make targeted changes to the contract and inter-firm controls.

\subsection{The Cotton CRC}

The Cotton CRC (the 'CRC') was established in 1993 under an Australian Government program to encourage collaboration between publicly funded researchers and private sector end-users (Slatyer 2000). ${ }^{10}$ The program rules limited the life of each CRC to seven years; however, the Cotton CRC was renewed twice and ran for 18 consecutive years. The CRC was structured as an equity-based joint venture, funded by a government grant and cash, capital and in-kind contributions from partnering organisations (see Figure 3). The centralised pool of resources was administered by a central management entity responsible for ensuring the venture's portfolio of projects delivered against the CRC's collective objectives.

\section{$<$ INSERT FIGURE 3 HERE $>$}

An "umbrella" structure was intended to overcome the competitive barriers between different research providers and facilitate a collaborative R\&D network (CRC Manager A). The CRC's collective objectives were formalised in two central contracts (the 'Agreements'), binding the partners to each other and the government. The Agreements were specified at the outset in the CRC's bid application, and prescribed many aspects of the CRC's operation, including

\footnotetext{
${ }^{10}$ The Cotton CRC is one of several hundred arrangements funded through the CRC Program since 1990.
} 
contributions, planned expenditures, initial projects, reporting and operating rules, and the residual decision rights allocated to internal managers. The Agreements reduced the scope for subsequent negotiations by establishing the partners' commitment to the strategic goals, budget and detailed operating plans for each seven-year term (CRC Manager C).

The central entity's staff were responsible for managing the R\&D portfolio, which was structured into research programs administered by program leaders. ${ }^{11}$ As most of the CRC partners were research agencies, most of the R\&D was initiated by issuing calls or tenders to the partner organisations. The program leaders then worked collaboratively with individual researchers to develop projects that met the CRC's objectives. Once initiated, the projects were then managed through simple monitoring mechanisms, including milestone progress reports, financial reports, final project reports, and project evaluations.

\subsubsection{Episode 4: Contracting with non-partner providers}

One of the most significant changes that occurred across the CRC's lifecycle was a rapid expansion in the scope of its R\&D portfolio coinciding with its second funding extension. This expansion, shown in Figure 4, was a strategic response to government expectations that each successive CRC venture should represent a distinct research offering from its predecessor (CRC Board Member A). The third Cotton CRC committed to delivering programs in its traditional areas (i.e. farming and textile products), and environmental sustainability and social community issues. However, as these new 'fringe' research programs lay outside the expertise of CRC partners, the alliance was forced to contract with non-partner providers (Researcher D).

\section{$<$ INSERT FIGURE 4 HERE $>$}

This situation presented several problems for the CRC. First, it rendered the original partner search process ineffective:

It was really hard to try and find people; so the communities program, the social research, was really slow to get going because we went down the typical avenues of putting calls out for

\footnotetext{
${ }^{11}$ Historically the program leaders were in-kind part-time roles performed by senior research scientists working at partner research agencies.
} 
projects... we had an initial call, and we did that twice and we still just ended up with projects that we couldn't even understand (CRC Manager A).

Second, whereas the scientists working for CRC partners were based in cotton-growing regions, the non-partner providers were located in metropolitan cities and had little experience in agriculture. This meant that non-partner providers often struggled to develop projects that fitted the industry's needs:

Whenever any project in the [environment] program started, there was a lot of liaison about connecting them to their end user because we also really struggled ... making sure that their conception models were real, that they had a realistic idea of what was going to be a useful output and what was a useful way of framing their question. Because it can all get a bit academic. (CRC Manager B)

There was also scepticism about the motives of non-partner providers - referred to as 'seagulls' - and concerns about whether they would fulfil their contractual obligations:

In the communities' program ... we joke about seagull researchers ... which you sort of have to be careful about. But they come in from out of bigger places, they shit everywhere, and they fly back out again... these guys make the mess and get the hell back out of there and write an academic paper from afar. (CRC Manager A)

This scepticism sat alongside a recognition that several alliance safeguards did not extend to nonpartners. For example, while partners had committed an equity stake and were contractually bound to achieve the CRC's collective objectives (CRC Partners Agreement), non-partner providers had no such stake and were only bound by one-off contracts. A further challenge was that much of the alliance's controls were well-established routines and familiar to provider partners by the third venture. The project initiation procedures, for example, had been formalised in a detailed workflow prescribed in the CRC Procedures Manual and embedded in staff work processes (CRC Procedures Manual). While these processes worked smoothly for traditional programs, they were less effective in procuring projects in the new programs:

With the classical production-related research...If I sent out a general call for research into heliocoverpa, entomology, et cetera, we would get 50 applications, ranging from $\$ 2000$ to $\$ 40$ million projects, and it would be world-class stuff...If you do the same in the social sciences area, 
we want to research into resilience in regional communities, the crap that comes back in is virtually unintelligible because it's the wrong way to go about it. (CRC Manager C)

Thus, the challenge was to find ways to manage non-partner providers that did not compromise the existing procedures used for the traditional programs. The solution was to introduce additional controls explicitly targeting the new research programs (CRC Manager A). For example, while the traditional programs continued to be led by partner organisations, two new full-time program leaders were hired to manage the new program areas. These program leaders used more intensive partner selection processes, replacing open calls with more prescriptive tenders for commissioned projects. In addition, both program leaders, who were proficient in environmental and social science, sought to identify, recruit, mentor and build relationships with a set of preferred providers - a process that took several years:

It's only been in the last few years after we've had a bit of trial and error with who can we work with and what sorts of ideas [come up], that we've started to get projects that are starting to be applied social research in a way. So that's been a real education of the researchers. (CRC

Manager A)

Finally, both program leaders spent more time monitoring projects. In addition to regular progress reports, program leaders frequently called or travelled to meet face-to-face with the non-partner providers. Their relational styles of managing projects enabled them to monitor their progress more directly, build ongoing relational ties and help these non-partner researchers deliver projects aligned with the CRC's priorities.

This episode of adaption arose when the existing alliance controls were ill-suited to changes in the scope of the CRC's research program and research partners. Rather than changing the configuration of the alliance to include new and unknown research partners, an additional set of management controls were created for transactions within the new program areas and managed by two program leaders whom the CRC employed.

\subsubsection{Episode 5: Ensuring R\&D contract compliance}

In 2009, halfway through the term of the third Cotton CRC, the partners learned that their application for further renewal of the joint venture had been unsuccessful. This shifted the alliance into a termination phase with a rigid delivery deadline. This was in contrast to the 
previous CRC ventures, where the alliance renewals enabled the partners to roll projects and resources into the following arrangement. The hard deadline to deliver the CRC objectives was made difficult by the collective nature of these targets. For example, one CRC objective was to increase cotton water efficiency by 50 per cent, which involved a combined investment of over $\$ 30 \mathrm{~m}$ across 80 different projects by over a hundred researchers. The collaborative and integrated nature of CRC's organisational structure made it difficult to assign accountability for delivering particular outcomes. This further compounded an ongoing challenge within the CRC, whereby managers often struggled to diagnose poor performance at a project level. When researchers failed to achieve outcomes, managers found it difficult to distinguish between relatively benign operational issues (such as people going on leave, studies not yielding expected results, weather conditions) from more opportunistic modifications to the project's scope. The danger was that for some researchers:

... they've ultimately had to compromise what they wanted to do in the name of actually getting funding, and then once they actually have their funding, they have just a natural inclination to migrate back to what they really wanted to do in the first instance. (CRC Manager C)

The CRC's Agreement with the government and its partners contained 60 discrete research outputs and over 250 milestones (CRC Partnership Agreement). Critically, this contract explicitly limited any option to renegotiate these precise performance targets, extend the lifetime or create a perpetual alliance arrangement:

From the CRC's perspective, we have an agreement with the [Australian Government] and the participants, all 11 participants, that says we will improve water use efficiency by 50 per cent, we will improve groundwater modelling by 10 per cent, we will increase the uptake of integrated pest management by 50 per cent. So that's the goal. Now the question is how the hell we get at it. (CRC Manager C)

The CRC managers, led by its CEO, responded to the new pressure to ensure contract compliance by increasing the intensity, frequency and formality of monitoring. Immediately after the unsuccessful application to renew the $\mathrm{CRC}$, a Chief Operating Officer was appointed to implement a CRC-wide monitoring and evaluation program (CRC Annual Report 2010). The program used specific performance indicators to monitor the progress of all projects, milestones and outcomes, identify portfolio gaps and risks, and manage the CRC's progress towards 
achieving its collective targets. The CRC Management Team (CMT) increased its meeting frequency from every six months to once a month, and all open projects were reviewed using a red-amber-green rating system. By leveraging the collective and diverse expertise of the CMT, managers could detect problem projects and intervene through closer monitoring, tighter expenditure control, or termination:

If the Program Leader thinks there's a problem with a project, then we know to hold the quarterly payment for those two quarters. ...It gives us an opportunity to say, this project is not on track, this is falling over, we need to step in and see how we can assist, or do we close this project off. Or they can come back and say, look, this is a seasonal thing, we'll be back on track and it continues. (CRC Manager D)

The more frequent meetings also cultivated a new culture of "failing fast" (CRC Manager C) and focusing on the projects with the highest risk:

You can't do everything, just have to pick the projects with the highest risk are the ones you worry about. Then the projects that potentially had the biggest impact in terms of our milestones, worry about those (CRC Manager B)

The formal monitoring was accompanied by more intense project supervision. Between formal progress reporting, program leaders maintained regular personal contact with researchers. While the increase in monitoring was 'painful' and 'exhausting' (CRC Manager B), they conceded it helped ensure the CRC met its contractual obligations:

"I think [the increase in monitoring] is a positive thing. Everybody gets the shits with reporting... But I think everybody realised that reporting is really important, that you've got to, again, measure to manage... It's just a necessity... Even the very last report had to be in by a couple of weeks before the end of the CRC, and I think there's only one [project] outstanding. So that must show something. People were inspired enough to really get in and do things on time, which is pretty unusual." (Research Provider G)

In this final episode, the termination deadline exposed an underlying problem in the alliance of ensuring contractual outcomes were delivered. The alliance managers responded by introducing additional alliance-wide controls that increased their capacity to monitor, manage and evaluate the completion of projects. 


\section{Discussion}

Table 5 summarises the case findings from the five adaptation episodes relating to the theoretical constructs of interest. Working left to right, this shows a consistent temporal sequence, whereby partners encountered an emergent risk, were constrained working within their earlier control choices and then made subsequent changes to the alliance controls.

\section{$<$ INSERT TABLE 5 HERE $>$}

The left columns show the disturbances that triggered each episode, be it changes in corporate governance requirements (Episode 1); revenue volatility and budget cuts (Episode 2 and 3); changes in scope (Episode 4); or the termination of the alliance funding (Episode 5). Consistent with prior theory (Ariño and de la Torre 1998; Doz 1996; Reuer and Ariño 2002; Ring and Van De Ven 1994; Williamson 1996), these contingencies appeared to undermine the efficient equilibrium of alliance controls and expose partners to risk. In some cases, the disturbances magnified an existing vulnerability, such as when the Cotton CRC's termination identified concerns about contract compliance (Episode 5). In others, it caused a new risk to materialise, such as when the imposition of a skills-based Board reduced its industry knowledge and created problems in project selection decisions (Episode 1). In terms of their substantive nature, most emergent risks were similar to those observed in less mature inter-firm contexts, including project selection and negotiation problems (Neumann 2010), contract compliance issues (Anderson and Dekker 2005), and hold-up hazards arising from dependence (Anderson et al. 2000; Dekker 2004; Donada and Nogatchewsky 2006). However, what distinguishes these risks as emergent is that they were triggered by events unanticipated at the alliances' formation and outside partners' control. Even if a particular contingency could be expected to occur at some point, uncertainty in the precise timing made planning for such circumstances difficult.

In the subsections to follow, we integrate our cross-case findings of the patterns depicted in Table 5 within a discussion of the theoretical implications of the study. This discussion is structured to address the two research aims: first, how prior control choices inhibit the capacity of partners of mature alliances to switch or differentiate established controls; and second, how partners work within such constraints to address emergent risks.

\subsection{Governance inseparability}


Despite the threats posed by emergent risks, we found evidence of both forms of governance inseparability - switching and differentiation - constraining control adaptation (Argyres and Liebeskind 1999, 2002). Despite the CRDC's problems with an inexperienced Board and unhappy research providers, the alliance did not move away from its centralised decision-making or competitive funding model (Episodes 1 and 2). Similarly, the CRC's problems in ensuring contract compliance did not lead it to abandon its collaborative joint venture model (Episode 5). Both alliances also experienced differentiation challenges as they struggled to manage their entire portfolio using a single control infrastructure. The CRC encountered difficulties in accommodating transactions with new providers in areas outside its original scope (Episode 4); whereas, the CRDC struggled with existing providers, who increasingly became dissatisfied with the CRDC's competitive model and short-term funding cycle (Episode 3).

Our evidence of governance inseparability raises several relevant insights for understanding the relation between alliance controls and risk. First, the limiting effect of initial control choices helps explain why prior studies find post-formation governance changes, particularly to contracts, to be relatively infrequent (Ariño et al. 2008; Duplat et al. 2020; Reuer and Ariño 2002; Reuer et al. 2002). Although we cannot infer statistical significance, we observed a similarly low rate of contractual renegotiation as these prior studies (one in five episodes), even in the context of significant environmental and strategic disruptions. The infrequency of contractual changes reinforces the view that opportunities to renegotiate may be more limited or costly (Duplat et al. 2020) and highlights the significance of getting the initial contract design 'right' (Doz 1996). Interestingly, our only episode of contractual renegotiation (Episode 3) at first appears to counter Duplat et al. (2020), who found that prior ties lessen the need for renegotiation. However, this may be explained by the poor quality of relations between parties whose prior experience had created mistrust to the point they anticipated 'war'. Without a sufficient 'shadow of the future'(i.e. expectations of continuity) to safeguard the exchange through relational means (Poppo et al. 2008), distrusting parties may have to resort to formal renegotiation of contracts.

Second, our results consistently indicate that control adaptation is not necessarily the smooth transition process depicted in alliance dynamics models (e.g. Doz 1996; Kumar and Nti 1998; Ring and Van De Ven 1994; Zajac and Olsen 1993) or prior empirical studies (Kamminga and 
Van der Meer-Kooistra 2007). Furthermore, the friction caused by existing controls suggests the existence of alliance-specific transaction costs, which may influence the efficient alignment of controls (Leiblein and Miller 2003; Williamson 1985). As the costs associated with controlling a particular transaction will be affected by an alliance's past governance choices, the extent to which these choices vary between alliances will cause variation in control arrangements for similar transactions. Previous scholars have warned that studying one-to-one associations between individual transactions and alliance controls may present "an incomplete and potentially biased picture of the important determinants of inter-firm management control practices" (Anderson and Dekker 2013, p.42, see also Tomkins 2001; Williamson 1985). They also caution against identifying 'misalignment' between governance structures and individual transactions (Anderson et al. 2017). Our results indicate that governance inseparability may indeed produce what appear to be suboptimal controls at an individual transaction level that may not be inefficient in a global sense once portfolio-level risks are considered. Thus, models of inter-firm control in mature settings may need appropriate alliance-level factors to capture the obligations created by the existing control infrastructure. ${ }^{12}$

Regarding the sources of governance inseparability, our results align, contradict and extend prior theory (Argyres and Liebeskind 1999, 2002). As previously theorised, we find evidence of contractual commitments engendering governance inseparability, particularly concerning switching constraints. In three episodes, explicit provisions embedded within the two alliance associational agreements prevented changes to the alliance infrastructure, including changes to decision-right allocations (Episode 1), funding models (Episode 2), and the alliance lifespan (Episode 5). However, in contrast to Argyres and Liebeskind (1999), we did not observe the theorised effect of changes in relative bargaining power. Relative bargaining power was salient when the CRDC became more reliant on core R\&D providers (Episode 3). However, rather than advocating for the continuation of existing arrangements, providers appeared to use their position to negotiate different contracting arrangements. This suggests that, depending on the control preferences of the newly influential party, changes in bargaining power may not necessarily cause governance inseparability by inhibiting future changes in alliance controls.

\footnotetext{
${ }^{12}$ These variables would differ from partner-specific factors, such as partner-specific experience (e.g. Argyres and Mayer 2007) or alliance-level factors relating to previous ventures, such as partners' prior ties (e.g. Duplat et al. 2020).
} 
Our findings also point to two additional potential sources of governance inseparability, explaining why prior control choices limit future options. The first is alliance-specific regulation, whereby legal rules specific to the type of venture determine how an alliance is structured and operated over its lifespan. This was salient in Episodes 1 and 2, where the CRDC-specific legislation constrained the options available to partners to adjust the alliance's decision-making structure and funding arrangements. Similarly, in Episode 4, once the CRC's bid for renewal was unsuccessful, the CRC program rules prevented the alliance from extending its limited life. Given government funders' involvement in both cases, it is perhaps unsurprising that regulation impinged on alliance partners' discretion. To some degree, all alliances are subject to legal rules and requirements, specifying how, where, and with whom an alliance is structured, which may constrain partner future control choices. The insights from this study add further nuance to understanding the role of regulation in inter-firm control. Previous studies have posited regulation as a contextual factor shaping the initial choice of controls (Van der Meer-Kooistra and Vosselman 2000) or a trigger for transiting between control patterns (Kamminga and Van der Meer-Kooistra 2007). While we observe something similar in Episode 1 (i.e. legislative change triggering a control adaptation episode), our results suggest that regulation may also be a force that constrains changes in alliance controls.

The other source of governance inseparability we observed stemmed from a desire to maintain consistency in alliance controls, both over time and across the portfolio of transactions. For instance, in Episode 2, we found that despite providers' requests, CRDC managers were reluctant to abandon their existing approach to strategic planning and project selection. In both Episodes 3 and 4, attempts to develop differential controls for certain providers had to be consistent with (i.e. not contradict) the alliances' standardised operating rules and procedures. The need for control consistency appears to reflect a range of other concerns of why prior control choices may limit the type and range of strategic options in the future. Similar to the findings of exit barriers in Phua et al. (2011), a desire for control consistency over time may reflect cost-efficiency concerns, where partners avoid incurring investment costs to establish new controls and opportunity costs of abandoning prior controls. The desire for control consistency may also reflect observations from Johansson and Siverbo (2011), who found that the internal congruence of the governance package to be a driver of alliance performance. A third explanation for why control consistency may impinge on strategic options relates to equity concerns, whereby 
offering differential control arrangements between providers may undermine the equity equilibrium of the alliance (Ariño and de la Torre 1998; Ring and Van De Ven 1994).

Our findings also extend the theory of governance inseparability by revealing the negative consequences switching and differentiation constraints pose for mature alliances. By 'locking in' partners to existing control configurations, switching constraints may act as an exit barrier (Leiblein and Miller 2003). This may not only prevent alliances from changing to an alternative supplier (Phua et al. 2011) but may also reduce their strategic options to respond to, adapt and remedy significant changes or disruptions in their operating environment. By comparison, new alliances may be less burdened by prior control choices and may have more freedom to design their alliance infrastructure to suit changing conditions. In addition, differentiation constraints appear to act as potential barriers to entry by limiting the range of activities an established alliance may pursue, particularly in innovation. Specifically, differentiation constraints may hamstring established alliances from pursuing new opportunities if they require significantly different control arrangements. Thus, both forms of governance inseparability may limit mature alliances' strategic options and leave them at a competitive disadvantage compared to alliances in their establishment phase.

On this point, it is worth considering an event that occurred concurrent to our study. In 2007, a research agency formed a new joint venture with a commercial seed distribution company to fund cotton long-term breeding programs, which the CRDC had previously funded. The new venture featured a partner co-contribution funding model, shared ownership rights over the resulting intellectual property, and a 10-year renewal horizon (Cotton RD\&E Strategy Working Group 2011). Given the concerns raised about the CRDC's competitive funding model, it appears the breeding program, which required investments in specific, non-transferable expertise and equipment, was better aligned with the governance offered by the new venture. In addition, the loss of the breeding programs to the new joint venture might explain why the CRDC was considering lengthening the contractual terms for similar transactions in Episode 3, which was the only contractual change we observed. Nonetheless, the loss of the breeding projects parallels similar patterns observed in biotechnology firms (Argyres and Liebeskind 2002), where their prior governance choices encumber incumbent alliances in a way that new alliances are not.

\subsection{Compensatory control}


The right-hand columns in Table 5 show that while partners may have been limited in the strategic options to renegotiate contracts and structural arrangements, they responded to emergent risks mainly through partner selection strategies and inter-firm management controls. This pattern counters Reuer et al. (2002), who found changes in monitoring mechanisms to be less frequent than contractual modifications, although our study considered a more comprehensive range of alliance controls.

In considering why partners opted to make these sorts of modifications, one advantage over the bluntness of structural or contractual change was the ability to match the scope of control response to that of the emergent risk. For endemic risks affecting the entire portfolio of transactions, partners made changes to partner-selection strategies (Episode 1), strategic planning processes (Episode 2) or monitoring mechanisms (Episode 5). For more idiosyncratic risks, they used strategies targeting only affected transactions, such as adjusting particular contracting terms (Episode 3) or introducing additional program-specific behaviour and output controls (Episode 4). In addition, these control adaptations also reflect the variety of emergent risks. For example, similar to prior studies, the introduction of more outcome and social controls enabled partners to address ex-post contracting concerns (Dekker 2004; Langfield-Smith and Smith 2003), and adjustments to planning helped alleviate ex-ante negotiation problems (Neumann 2010). Perhaps more significantly, our results highlight the versatility of partner selection strategies in attending to a wide range of risks. Specifically, Episodes 2, 3 and 4 reinforce prior studies showing that the careful search and selection of partners can ameliorate relational and behavioural problems (Dekker 2008; Li et al. 2008), while Episode 1 speaks to their capacity to reduce risk by remedying information gaps (Dekker and Van den Abbeele 2010; Ding et al. 2013).

A pattern of more targeted adaptations within a governance package points to the contribution management controls make to ensuring the sustainability and diversity of alliances (Anderson and Dekker 2013; van den Bogaard and Speklé 2003). Similar to the 'repair work' observed in Mahama and Chua (2016), when emergent concerns could not be alleviated by changing to the existing infrastructure, the alliance may be preserved using other control strategies. This suggests how management controls enable the resilience of hybrid forms, which were initially dismissed for being unstable or temporary organisational forms (Ménard 2004; Williamson 1985, 1991). Also, the use of controls to accommodate transactions that would otherwise be misaligned 
widens the allowable scope of an alliance. This may explain why different hybrid forms can coexist within similar transactional contexts (Ménard 2013) by identifying how contrasting hybrid structures effectively manage similar transactions.

This control adaptation pattern also reveals a particular type of relation between controls implemented at different times in response to different risks. While some alliance controls were implemented to attend to risks envisioned at the alliance's formation, other controls were introduced later to address emergent risks. The new controls do not substitute or replace the established controls, which remain in place. Instead, the governance package is expanded as new controls compensate for any weakness in the original control infrastructure. For example, in Episode 5, we see more intense and frequent monitoring mechanisms to compensate for the compliance problems created by collective alliance targets. In Episode 2, more flexible strategic plans are introduced to compensate for the uncertainty created by variation in R\&D funding.

This 'compensatory control' relation between the established and new controls appears to diverge from the conventional substitute/complementary dichotomy explored in prior inter-firm studies (e.g. Dekker 2008; Dekker and Van den Abbeele 2010; Duplat et al. 2020; Li et al. 2008; Poppo and Zenger 2002; Stouthuysen et al. 2017). In the broader management control literature, there have been some recent attempts to add nuance to the somewhat strict interpretation of what complementary controls are (Grabner \& Moers 2013), including what has been couched as 'compensating effects' (e.g. Bedford 2020; Huber et al. 2013). While we would see compensatory controls as exhibiting complementary features, such as positive reinforcement, our empirical evidence suggests at least two characteristics distinguish compensatory from complementary controls.

First is that the relevant controls are interdependent, arising from how they relate to what scholars label as the focal 'control problem' (Bedford et al. 2016; Grabner and Moers 2013). According to Grabner and Moers (2013), both substitute and complementary relations occur when controls are interdependent, in that they both attend to the same control problem (control risk). In contrast, controls that attend to unrelated control problems should be considered independent of each other (i.e., unrelated). However, our case findings show how the use of one control (e.g. collective alliance targets in Episode 5) to attend to one control problem (e.g. alignment of partner interests) causes the emergence of a secondary control problem (e.g. 
difficulty in ensuring contract compliance), which necessitates the use of a second, compensatory control (e.g. more frequent monitoring mechanisms). In such scenarios, the two controls attend to different control problems, yet the problems are not entirely unrelated as the remedy to one problem becomes the contributing source for another. Although the second problem may be eliminated by abandoning the problematic control design, i.e. thought control avoidance (Merchant and Van der Stede 2003), if there is a reluctance or inability to do so, then using an additional compensatory control becomes a viable alternative. As such, compensatory relations occur when the emergence of a control problem is caused by or made more salient by the established control infrastructure, which necessitates the addition of compensatory control.

The second is the separate timing of when the relevant controls are introduced. Compensatory controls are introduced to address the secondary control problem, which emerges some time after the initial governance package design. Had the control problem existed or been salient when the alliance was established, it would have been addressed in the initial design using a combination of complementary controls, i.e. controls that mitigate each other's weaknesses (Bedford 2020; Huber et al. 2013). Only once a dysfunction in the established controls emerges, often prompted by some unanticipated shock or disturbance, does the use of compensatory controls become necessary. For this reason, compensatory control relations are more likely to exist within established control configurations that encounter significant change or disturbances.

These two characteristics of compensatory control - interdependencies arising from related control problems and the separate timing of implementation - reminds us of the potential unintended consequences of control choices (e.g. Anderson et al. 2017; Mouritsen et al. 2001; Stouthuysen et al. 2019). Further, as both characteristics may only be discerned by investigating the origins, dynamics and trajectories of control combinations, this reinforces the value of studying control relations over time (Huber et al. 2013; Mahama and Chua 2016).

\section{Conclusion}

In this study, we have sought to understand how alliances manage risk over time by examining the adaptation constraints created by partners' earlier control choices. Our longitudinal study identifies five episodes of change, enabling us to trace how the existing control infrastructure of two alliances limited their ability to switch or differentiate their control strategies that had 
become compromised by unanticipated, emergent risks. However, we also found that these constraints did not prevent all types of adaptation, as partners compensated for emergent control problems by introducing targeted, additional elements to their governance packages.

The study extends the inter-firm literature to explain how partners manage and control risk over the lifecycle of an alliance. While prior work illuminates the role of control choices made during the start-up or development phases of an alliance, this study draws attention to the additional control complexities which arise during the mature phase - and through to termination. Specifically, we demonstrate the relevance of governance inseparability (Argyres and Liebeskind $1999,2002)$ in explaining why partners of mature alliances, having made initial choices about their controls during the establishment phase, are limited in adapting their control arrangements subsequently. This enhances our understanding of the control-risk relation by explaining why expost control adaptation may not be as straightforward as previously thought (Ariño et al. 2008; Duplat et al. 2020; Reuer and Ariño 2002; Reuer et al. 2002). Also, by examining adaptations made to established governance packages, we identify a new type of compensatory relation between controls implemented to attend to different problems at different times. This extends our understanding of the nature of relations between alliance controls (Duplat et al. 2020; Grabner and Moers 2013; Huber et al. 2013; Stouthuysen et al. 2017) and helps explain how controls contribute to alliance sustainability and diversity.

As this study was exploratory, we acknowledge several limitations in scope. First, we examined two alliances operating in one specific industry. There remain many other forms that may have different implications for control adaptations, particularly in alliances not established by legislation and where partners have more discretion to make structural changes or renegotiate contracts (Ménard 2013). While the episodes identified were relevant to understanding adaptation constraints, we do not assume that prior choices necessarily always have a constraining or inhibiting role. As contributions from organisational studies show, an organisation's history may also play an enabling role (Garud et al. 2010), whereby specific control structures may create opportunity, flexibility or innovation for an alliance to develop (Boland Jr et al. 2008; Mouritsen and Thrane 2006; Thrane 2007). Also, while two of our episodes pointed to the challenges of managing diverse portfolios of transactions, there remains significant scope to examine the 'portfolio problem' of inter-firm arrangements (Tomkins 2001). 
Future work could examine how alliance partners configure controls to portfolio- rather than transaction-level characteristics, how partners manage more homogenous versus diverse bundles of transactions, and how partners manage the potential trade-offs of segmentation strategies (Cooper and Slagmulder 2004; Gietzmann 1996; Mouritsen et al. 2001). Finally, while longitudinal analysis allowed us to observe the dynamics between controls and risk over time, further work is needed to examine the implications of such choices for alliance outcomes. In particular, future studies may explore the potential implications of control adaptations on the 'internal congruence' of governance packages (Johansson and Siverbo 2011) or the perceived equity of the alliance control arrangements (Ariño and de la Torre 1998; Doz 1996). These issues point to the opportunity to investigate how partners manage and control risk over the lifecycle of alliances and further understand the imperative and constraints in adapting to new and emergent circumstances. 


\section{References}

Anderson, S.W., Christ, M.H., Dekker, H.C., Sedatole, K.L., 2014. The use of management controls to mitigate risk in strategic alliances: Field and survey evidence. Journal of Management Accounting Research 26, 1-32.

Anderson, S.W., Dekker, H.C., 2005. Management control for market transactions: The relation between transaction characteristics, incomplete contract design, and subsequent performance. Management Science 51, 1734-1752.

Anderson, S.W., Dekker, H.C., 2010. Accounting in networks: The transaction cost economics perspective, in: Håkansson, H., Kraus, K., Lind, J. (Eds.), Accounting in Networks. Routledge, New York, pp. 235-268.

Anderson, S.W., Dekker, H.C., 2013. The role of management controls in transforming firm boundaries and sustaining hybrid organizational forms. Foundations and Trends in Accounting 8, 75-141.

Anderson, S.W., Dekker, H.C., Abbeele, A.V.d., 2017. Costly control: An examination of the trade-off between control investments and residual risk in interfirm transactions. Management Science 63, 21632180.

Anderson, S.W., Glenn, D., Sedatole, K.L., 2000. Sourcing parts of complex products: Evidence on transactions costs, high-powered incentives and ex-post opportunism. Accounting, Organizations and Society 25, 723-749.

Argyres, N., Mayer, K.J., 2007. Contract design as a firm capability: An integration of learning and transaction cost perspectives. Academy of management review 32, 1060-1077.

Argyres, N.S., Liebeskind, J.P., 1999. Contractual commitments, bargaining power, and governance inseparability: Incorporating history into transaction cost theory. Academy of Management Review 24, 49-63.

Argyres, N.S., Liebeskind, J.P., 2002. Governance inseparability and the evolution of US biotechnology industry. Journal of Economic Behavior \& Organization 47, 197-219.

Ariño, A., de la Torre, J., 1998. Learning from failure: Towards an evolutionary model of collaborative ventures. Organization Science 9, 306-325.

Ariño, A., Ragozzino, R., Reuer, J.J., 2008. Alliance dynamics for entrepreneurial firms. Journal of Management Studies 45, 147-168.

Azevedo, P.F., Silva, V.L.S., 2007. Governance inseparability in franchising: Multi-case study in France and Brazil, in: Cliquet, G., Tuunanen, M., Hendrikse, G., Windsperger, J. (Eds.), Economics and Management of Networks: Franchising, Strategic Alliances, and Cooperatives. Physica-Verlag HD, Heidelberg, pp. 97-115.

Bedford, D.S., 2020. Conceptual and empirical issues in understanding management control combinations. Accounting, Organizations and Society 86, 101187.

Bedford, D.S., Malmi, T., Sandelin, M., 2016. Management control effectiveness and strategy: An empirical analysis of packages and systems. Accounting, Organizations and Society 51, 12-28.

Boland Jr, R.J., Sharma, A.K., Afonso, P.S., 2008. Designing management control in hybrid organizations: The role of path creation and morphogenesis. Accounting, Organizations and Society 33, 899-914.

Caglio, A., Ditillo, A., 2008. A review and discussion of management control in inter-firm relationships: Achievements and future directions. Accounting, Organizations and Society 33, 865-898.

Cooper, R., Slagmulder, R., 2004. Interorganizational cost management and relational context.

Accounting, Organizations and Society 29, 1-26.

Cotton RD\&E Strategy Working Group, 2011. Cotton Sector Research Development and Extension:

Final Strategy.

Das, T.K., Teng, B.S., 1996. Risk types and inter-firm alliance structures. Journal of Management Studies $33,827-843$. 
Dekker, H.C., 2004. Control of inter-organizational relationships: Evidence on appropriation concerns and coordination requirements. Accounting, Organizations and Society 29, 27-49.

Dekker, H.C., 2008. Partner selection and governance design in interfirm relationships. Accounting, Organizations and Society 33, 915-941.

Dekker, H.C., Van den Abbeele, A., 2010. Organizational learning and interfirm control: The effects of partner search and prior exchange experiences. Organization Science 21, 1233-1250.

Ding, R., Dekker, H.C., Groot, T., 2013. Risk, partner selection and contractual control in interfirm relationships. Management Accounting Research 24, 140-155.

Donada, C., Nogatchewsky, G., 2006. Vassal or lord buyers: How to exert management control in asymmetric interfirm transactional relationships? Management Accounting Research 17, 259-287.

Doz, Y.L., 1996. The evolution of cooperation in strategic alliances: Initial conditions or learning processes? Strategic Management Journal 17, 55-83.

Duplat, V., Klijn, E., Reuer, J., Dekker, H., 2020. Renegotiation of joint venture contracts: The influence of boards of directors and prior ties as alternative governance mechanisms. Long Range Planning 53, 101856.

Eisenhardt, K.M., 1989. Building Theories from Case Study Research. Academy of Management Review $14,532-550$.

Eisenhardt, K.M., Graebner, M.E., 2007. Theory building from cases: Opportunities and challenges. Academy of Management Journal 50, 25-32.

Garud, R., Kumaraswamy, A., Karnøe, P., 2010. Path dependence or path creation? Journal of management studies $47,760-774$.

Geyskens, I., Steenkamp, J.-B.E.M., Kumar, N., 2006. Make, buy, or ally: A transaction cost theory metaanalysis. Academy of Management Journal 49, 519-543.

Gietzmann, M.B., 1996. Incomplete contracts and the make or buy decision: Governance design and attainable flexibility. Accounting, Organizations and Society 21, 611-626.

Gietzmann, M.B., Larsen, J.G., 1998. Motivating subcontractors to perform development and design tasks. Management Accounting Research 9, 285-309.

Grabner, I., Moers, F., 2013. Management control as a system or a package? Conceptual and empirical issues. Accounting, Organizations and Society 38, 407-419.

Gulati, R., Singh, H., 1998. The architecture of cooperation: Managing coordination costs and appropriation concerns in strategic alliances. Administrative Science Quarterly 43, 781-814. Handley, S.M., 2017. How governance misalignment and outsourcing capability impact performance. Production and Operations Management 26, 134-155.

Huber, T.L., Fischer, T.A., Dibbern, J., Hirschheim, R., 2013. A Process Model of Complementarity and Substitution of Contractual and Relational Governance in IS Outsourcing. Journal of Management Information Systems 30, 81-114.

Johansson, T., Siverbo, S., 2011. Governing cooperation hazards of outsourced municipal low contractibility transactions: An exploratory configuration approach. Management Accounting Research 22, 292-312.

Kamminga, P.E., Van der Meer-Kooistra, J., 2007. Management control patterns in joint venture relationships: A model and an exploratory study. Accounting, Organizations and Society 32, 131-154. Kumar, R., Nti, K.O., 1998. Differential learning and interaction in alliance dynamics: A process and outcome discrepancy model. Organization Science 9, 356-367.

Langfield-Smith, K., 2008. The relations between transactional characteristics, trust and risk in the startup phase of a collaborative alliance. Management Accounting Research 19, 344-364.

Langfield-Smith, K., Smith, D., 2003. Management control systems and trust in outsourcing relationships. Management Accounting Research 14, 281-307.

Leiblein, M.J., 2003. The Choice of Organizational Governance Form and Performance: Predictions from Transaction Cost, Resource-based, and Real Options Theories. Journal of Management 29, 937-961.

Leiblein, M.J., Miller, D.J., 2003. An Empirical Examination of Transaction- and Firm-Level Influences on the Vertical Boundaries of the Firm. Strategic Management Journal 24, 839-859. 
Leiblein, M.J., Reuer, J.J., Dalsace, F., 2002. Do make or buy decisions matter? The influence of organizational governance on technological performance. Strategic Management Journal 23, 817-833. Li, D., Eden, L., Hitt, M.A., Ireland, R.D., 2008. Friends, acquaintances, or strangers? Partner selection in R\&D Alliances. The Academy of Management Journal 51, 315-334.

Liebowitz, S.J., Margolis, S.E., 1995. Path dependence, lock-in, and history. Journal of Law, Economics, \& Organization 11, 205-226.

Lind, J., Thrane, S., 2010. Towards accounting in network settings, in: Håkansson, H., Kraus, K., Lind, J. (Eds.), Accounting in Networks. Routledge, London, pp. 60-79.

Macher, J.T., Richman, B.D., 2008. Transaction cost economics: An assessment of empirical research in the social sciences. Business and Politics 10, 1-63.

Mahama, H., Chua, W.F., 2016. A study of alliance dynamics, accounting and trust-as-practice.

Accounting, Organizations and Society 51, 29-46.

Mayer, K.J., Argyres, N.S., 2004. Learning to contract: Evidence from the personal computer industry. Organization Science 15, 394-410.

Ménard, C., 2004. The economics of hybrid organizations. Journal of Institutional and Theoretical Economics 160, 345-376.

Ménard, C., 2013. Hybrid modes of organization: Alliances, joint ventures, networks, and other strange animals, in: Gibbons, R., Roberts, J. (Eds.), The Handbook of Organizational Economics. Princeton University Press, Princeton, NJ, pp. 1066-1108.

Merchant, K.A., Van der Stede, W.A., 2003. Management control systems: Performance measurement, evaluation and incentives. Prentice Hall, Harlow, England.

Miles, M.B., Huberman, A.M., Saldaña, J., 2014. Qualitative data analysis: a methods sourcebook, 3 ed. SAGE Publications, Inc., Thousand Oaks, Califorinia.

Mouritsen, J., Hansen, A., Hansen, C.Ø., 2001. Inter-organizational controls and organizational competencies: Episodes around target cost management/functional analysis and open book accounting. Management Accounting Research 12, 221-244.

Mouritsen, J., Thrane, S., 2006. Accounting, network complementarities and the development of interorganisational relations. Accounting, Organizations and Society 31, 241-275.

Neumann, K., 2010. Ex-ante governance decisions in inter-organizational relationships: A case study in the airline industry. Management Accounting Research 21, 220-237.

Oxley, J., 1997. Appropriability hazards and governance in strategic alliances. Journal of Law and Economics, and Organization 13, 387-409.

Phua, Y.S., Abernethy, M.A., Lillis, A.M., 2011. Controls as exit barriers in multiperiod outsourcing arrangements. Accounting Review 86, 1795-1834.

Pisano, G.P., 1989. Using equity participation to support exchange: Evidence from the biotechnology industry. Journal of Law, Economics, and Organization 5, 109-126.

Poppo, L., Zhou, K.Z., Ryu, S., 2008. Alternative Origins to Interorganizational Trust: An Interdependence Perspective on the Shadow of the Past and the Shadow of the Future. Organization Science 19, 39-55.

Poppo, L.P., Zenger, T.R., 2002. Do formal contracts and relational governance act as substitutes or complements? Strategic Management Journal 23, 707-725.

Reuer, J.J., Ariño, A., 2002. Contractual renegotiations in strategic alliances. Journal of Management 28, 47-68.

Reuer, J.J., Ariño, A., 2007. Strategic alliance contracts: Dimensions and determinants of contractual complexity. Strategic Management Journal 28, 313-330.

Reuer, J.J., Zollo, M., Singh, H., 2002. Post-formation dynamics in strategic alliances. Strategic Management Journal 23, 135-151.

Reusen, E., Stouthuysen, K., 2020. Trust transfer and partner selection in interfirm relationships. Accounting, Organizations and Society 81, 101081.

Ring, P.S., Van De Ven, A.H., 1994. Developmental processes of cooperative interorganizational relationships. Academy of Management Review 19, 90-118. 
Saldana, J., 2013. The coding manual for qualitative researchers, 2nd ed. ed. Los Angeles : SAGE, Los Angeles.

Saldaña, J., 2013. The coding manual for qualitative researchers. SAGE, Los Angeles.

Sampson, R.C., 2004. The cost of misaligned governance in R\&D alliances. Journal of Law, Economics, and Organization 20, 484-526.

Slatyer, R.O., 2000. Cooperative Research Centres - A Retrospective View, Annual Meeting of the CRC Association, Brisbane.

Speklé, R.F., 2001. Explaining management control structure variety: A transaction cost economics perspective. Accounting, Organizations and Society 26, 419-441.

Stouthuysen, K., Slabbinck, H., Roodhooft, F., 2017. Formal controls and alliance performance: The effects of alliance motivation and informal controls. Management Accounting Research 37, 49-63.

Stouthuysen, K., Van den Abbeele, A., van der Meer-Kooistra, J., Roodhooft, F., 2019. Management control design in long-term buyer-supplier relationships: Unpacking the learning process. Management Accounting Research 45, 100643.

Sydow, J., Schreyögg, G., Koch, J., 2009. Organizational Path Dependence: Opening the Black Box. The Academy of Management Review 34, 689-709.

Thrane, S., 2007. The complexity of management accounting change: Bifurcation and oscillation in schizophrenic inter-organisational systems. Management Accounting Research 18, 248-272.

Tomkins, C., 2001. Interdependencies, trust and information in relationships, alliances and networks. Accounting, Organizations and Society 26, 161-191.

Uhrig, J., 2003. Review of the corporate governance of statutory authorities and office holders, in: Australia, C.o. (Ed.), Canberra, Australia.

van den Bogaard, M.A., Speklé, R.F., 2003. Reinventing the hierarchy: Strategy and control in the Shell Chemicals carve-out. Management Accounting Research 14, 79-93.

Van der Meer-Kooistra, J., Vosselman, E.G.J., 2000. Management control of interfirm transactional relationships: The case of industrial renovation and maintenance. Accounting, Organizations and Society 25, 51-77.

Vélez, M.L., Sánchez, J.M., Álvarez-Dardet, C., 2008. Management control systems as interorganizational trust builders in evolving relationships: Evidence from a longitudinal case study. Accounting, Organizations and Society 33, 968-994.

Williamson, O.E., 1985. The economic institutions of capitalism: Firms, markets, relational contracting. The Free Press, New York.

Williamson, O.E., 1991. Comparative economic organization: The analysis of discrete structural alternatives. Administrative Science Quarterly 36, 269-296.

Williamson, O.E., 1996. The mechanisms of governance. Oxford University Press, New York. Williamson, O.E., 1998. Transaction cost economics: How it works; where it is headed. De Economist 146, 23-58.

Yin, R.K., 2003. Case study research: Design and methods, 3 ed. Sage Publications, Thousand Oaks. Zajac, E.J., Olsen, C.P., 1993. From transaction cost to transactional value analysis: Implications for the study of interorganizationa strategies. Journal of Management Studies 30, 131-145. 
Table 1: Descriptive information about two $R \& D$ alliances

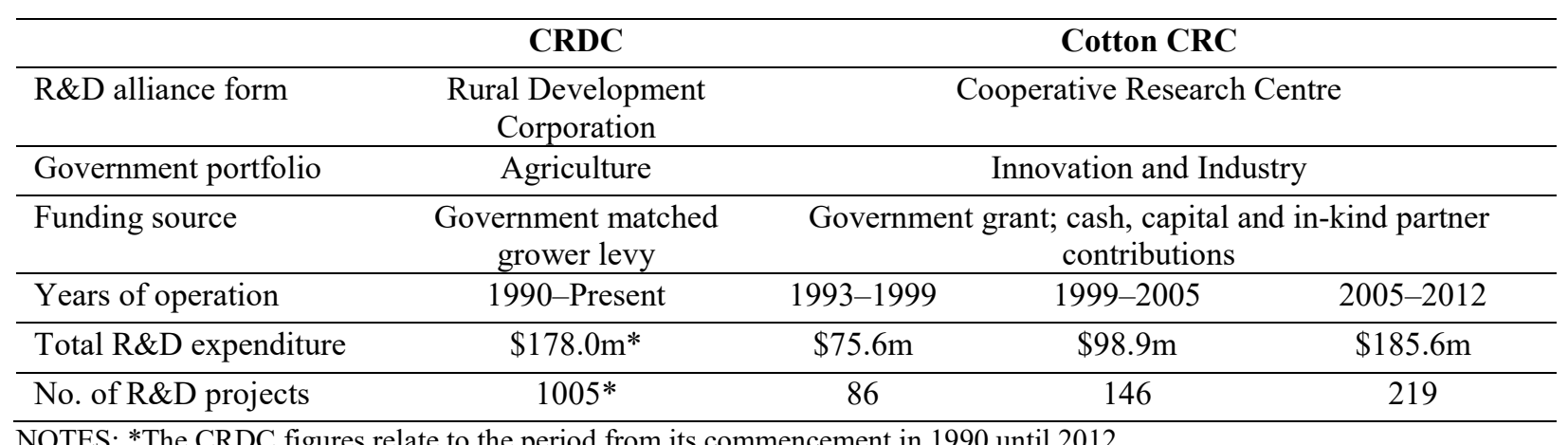

NOTES: *The CRDC figures relate to the period from its commencement in 1990 until 2012

Table 2: List of site visits and field trips

\begin{tabular}{llllr}
\hline $\begin{array}{l}\text { Field } \\
\text { trip \# }\end{array}$ & Period & Site(s) & \multicolumn{1}{c}{ Location } & $\begin{array}{l}\text { Duration } \\
\text { (days) }\end{array}$ \\
\hline $\mathbf{1}$ & Jun-12 & Two research providers & Sydney & 1.0 \\
\hline $\mathbf{2}$ & Jun-12 & $\begin{array}{l}\text { Headquarters of CRDC and Cotton CRC; Australian Cotton } \\
\text { Research Institute (ACRI) }\end{array}$ & Narrabri & 2.0 \\
\hline $\mathbf{3}$ & Aug-12 & The 16 $6^{\text {th }}$ Australian Cotton Conference & $\begin{array}{l}\text { Gold } \\
\text { Coast }\end{array}$ & 3.0 \\
\hline $\mathbf{4}$ & Aug-12 & Headquarters of Cotton Australia & Sydney & 0.5 \\
\hline $\mathbf{5}$ & Sep-12 & Headquarters of Cotton Australia & Sydney & 0.5 \\
\hline $\mathbf{6}$ & Sep-12 & $\begin{array}{l}\text { ACRI; Headquarters of Cotton CRC and CRDC; Site visits to } \\
\text { commercial cotton organisations }\end{array}$ & Narrabri & 11.0 \\
\hline $\mathbf{7}$ & Nov-12 & Headquarters of Cotton Australia & Sydney & 0.5 \\
\hline $\mathbf{8}$ & Nov-12 & Cotton Australia Panel review meetings; Cotton Australia AGM & Sydney & 2.0 \\
\hline $\mathbf{9}$ & Sep-13 & $\begin{array}{l}\text { The Australian Cotton Research Conference; Headquarters of } \\
\text { CRDC }\end{array}$ & Narrabri & 3.0 \\
\hline $\mathbf{1 0}$ & Oct-13 & $\begin{array}{l}\text { ACRI; Headquarters of CRDC; Site visits to commercial cotton } \\
\text { producers }\end{array}$ & $\begin{array}{l}\text { Narrabri; } \\
\text { Moree }\end{array}$ & 5.0 \\
\hline $\mathbf{1 1}$ & Mar-14 & Headquarters of Cotton Australia & Sydney & 0.5 \\
\hline & & & Total (days) & $\mathbf{2 9 . 0}$ \\
\hline
\end{tabular}

Table 3: Interviews by organisation

\begin{tabular}{lccc}
\hline Organisation & Interviews & Interviewees* $^{*}$ & Length (total hrs) $^{* *}$ \\
\hline CRDC & 10 & 8 & 10.75 \\
\hline Cotton CRC & 12 & 11 & 10.75 \\
\hline Research providers (5 organisations) & 22 & 21 & 20.75 \\
\hline Cotton Australia & 11 & 9 & 15.25 \\
\hline Commercial cotton organisations (4 organisations) & 6 & 7 & 5.5 \\
\hline Extension consultants & 3 & 3 & 2.75 \\
\hline Total & $\mathbf{6 4}$ & $\mathbf{5 9}$ & $\mathbf{6 5 . 7 5}$ \\
\hline
\end{tabular}

NOTES: * The number of interviewees represents the number of unique individuals interviewed as part of the study. This varies from the total number of interviews as occasionally, more than one individual was interviewed at a time (i.e. group interview), and some individuals were interviewed multiple times. ** Of the 64 interviews, 59 were digitally recorded and transcribed; during the remaining five interviews, researchers took notes. 
Table 4: Summary of alliance controls of the CRDC and Cotton CRC, as at 2007

\begin{tabular}{lll}
\hline $\begin{array}{l}\text { Governance } \\
\text { structure }\end{array}$ & Competitive subcontracting arrangement & Collaborative equity-based joint venture \\
\hline Contract & $\begin{array}{l}\text { PIERD Act and CRDC Deed } \\
\text { Individual project contracts (1-3 years) }\end{array}$ & $\begin{array}{l}\text { CRC Bid application } \\
\text { Long-term partner agreements }\end{array}$ \\
\hline $\begin{array}{l}\text { Partner } \\
\text { search and } \\
\text { selection }\end{array}$ & $\begin{array}{l}\text { Competitive annual open call and proposal } \\
\text { process }\end{array}$ & $\begin{array}{l}\text { Initial project list with partner providers } \\
\text { Program leader initiated calls and tenders } \\
\text { with partner providers }\end{array}$ \\
\hline $\begin{array}{l}\text { Inter-firm } \\
\text { management evaluation and selection }\end{array}$ & 5-year strategic plan & 7-year strategic plan \\
controls & Annual operating plan, budget and cash & $\begin{array}{l}\text { Annual operational plan, budget and } \\
\text { reporting }\end{array}$ \\
& reserves & Milestone project progress reports \\
& Annual reporting & Financial reporting \\
& Quarterly financial reporting & $\begin{array}{l}\text { Project evaluation and sign-offs by program } \\
\text { leaders } \\
\text { Co-location with providers }\end{array}$ \\
& Bi-annual project progress reporting &
\end{tabular}

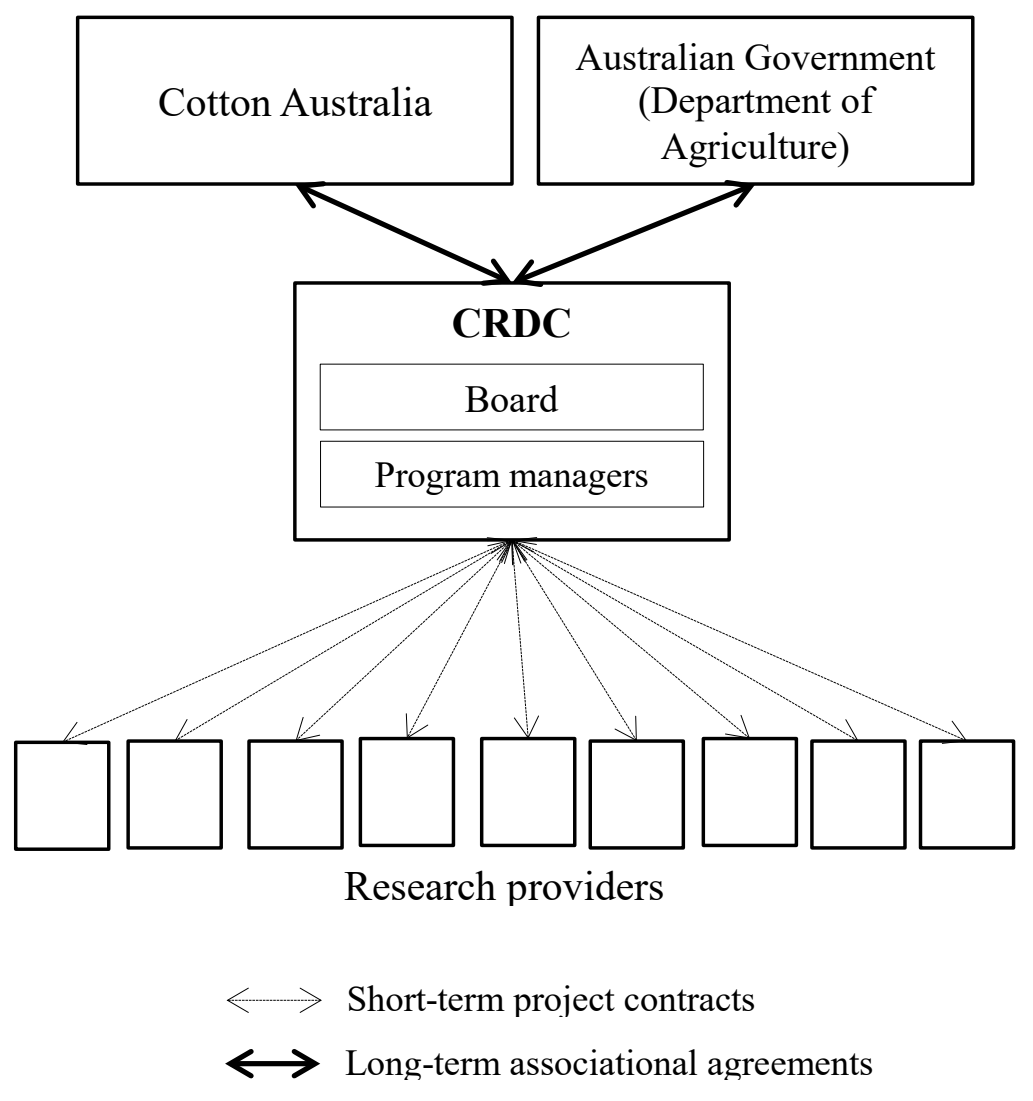

Figure 1: $R \& D$ contracting through the CRDC 


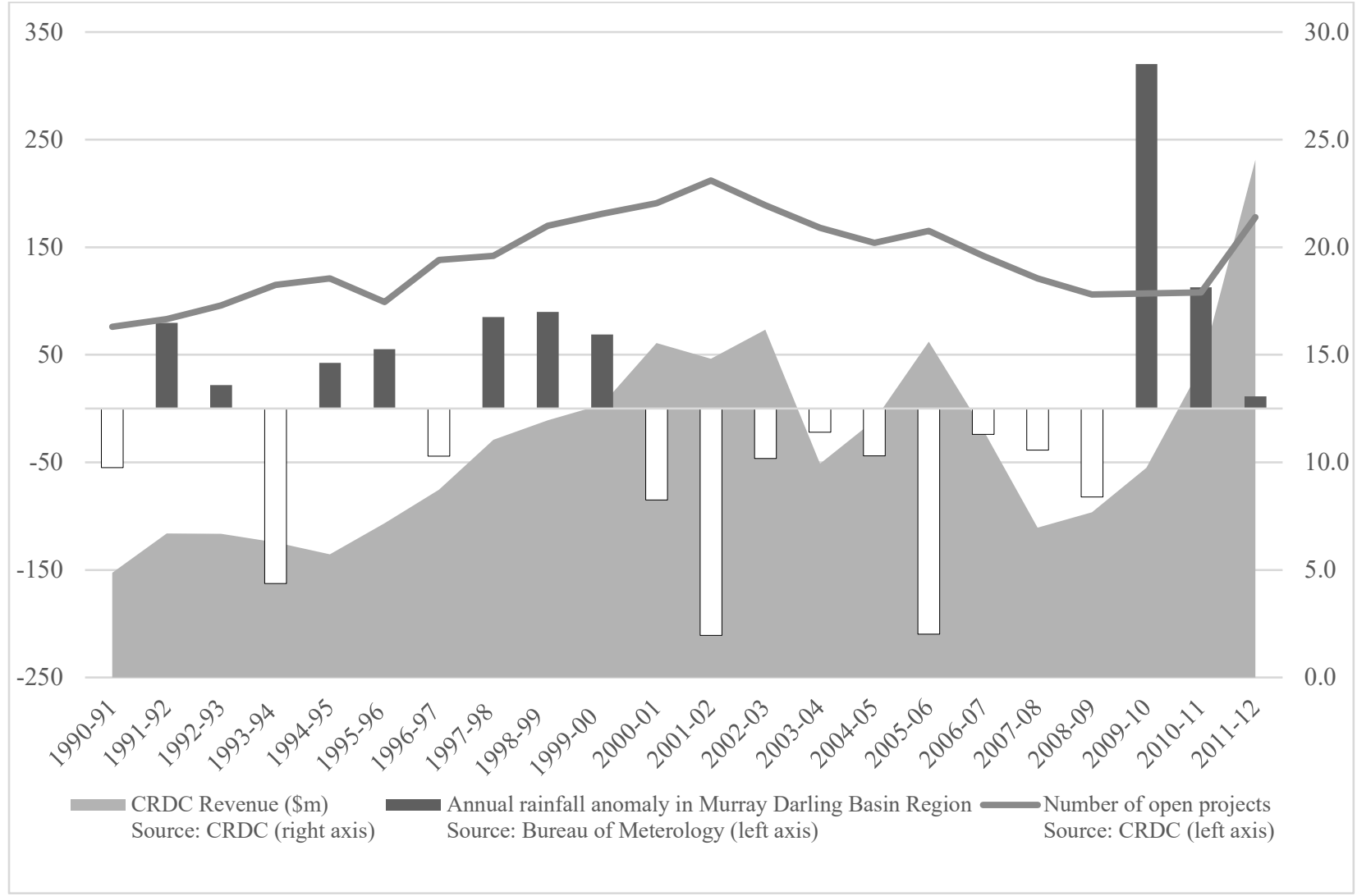

Figure 2: The seasonality of the CRDC's research funding 


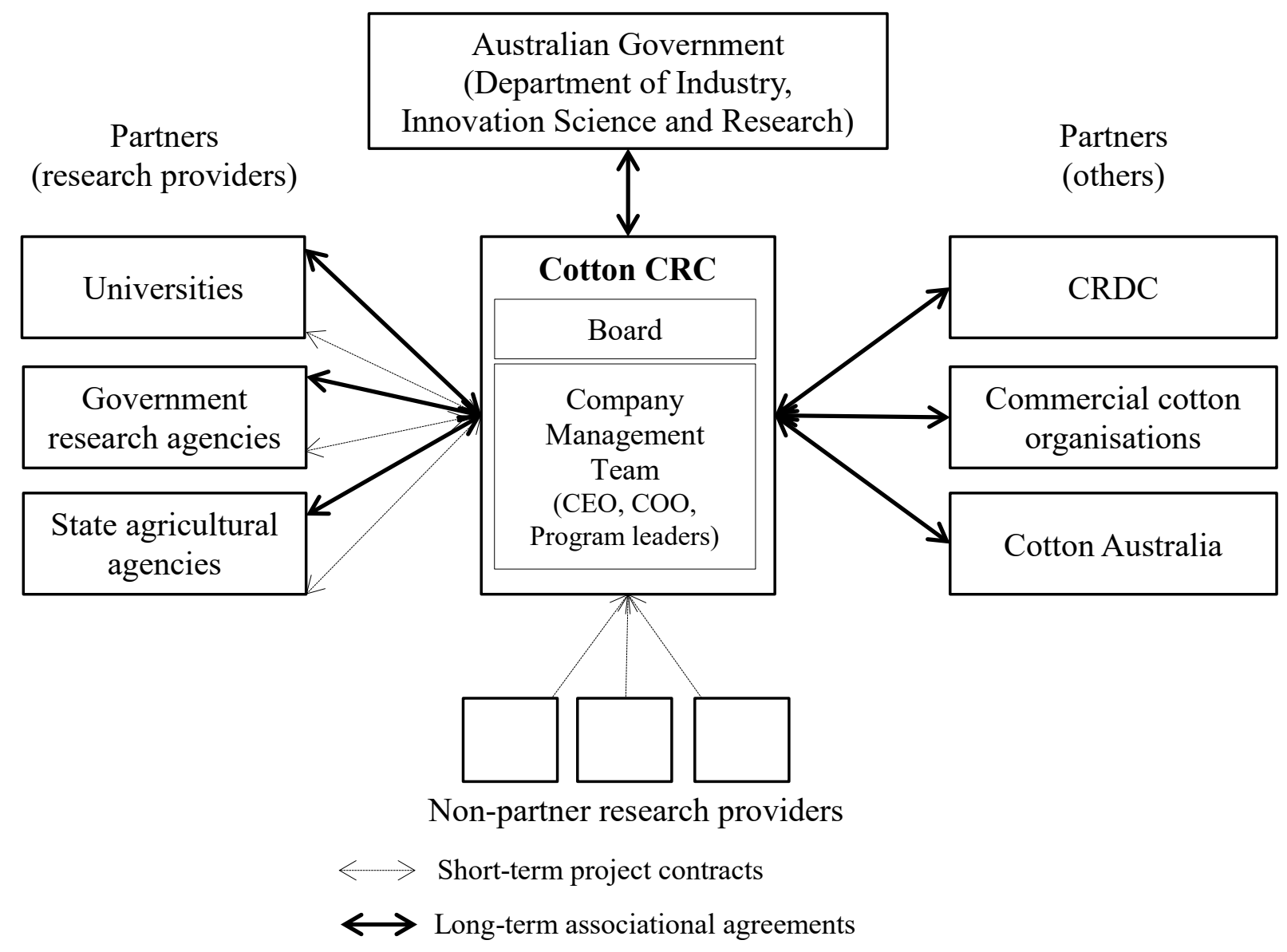

Figure 3: R\&D contracting through the Cotton CRC 


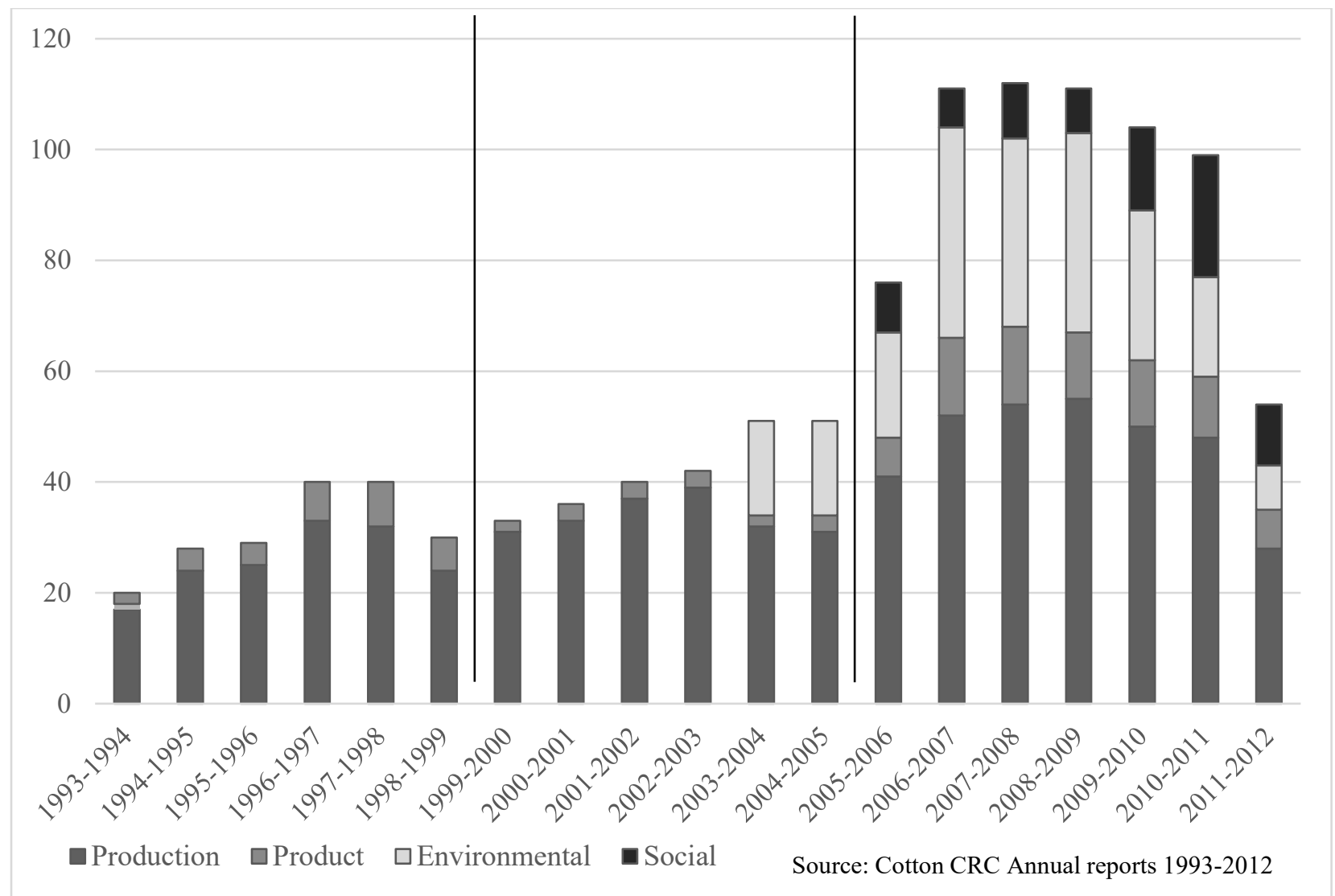

Figure 4: Number of open R\&D projects in the Cotton CRC, by Program 
Table 5: Episodes of alliance control adaptation

\begin{tabular}{|c|c|c|c|c|c|c|c|c|c|}
\hline \multirow[b]{2}{*}{ Case } & \multirow[b]{2}{*}{ Episode } & \multicolumn{3}{|c|}{ Emergent control risk } & \multicolumn{2}{|c|}{ Governance inseparability } & \multicolumn{3}{|c|}{ Changes to alliance controls } \\
\hline & & Disturbance & Risk & Risk scope & $\begin{array}{c}\text { Type of } \\
\text { constraint }\end{array}$ & Source & Contract & $\begin{array}{l}\text { Partner search } \\
\text { and selection }\end{array}$ & Inter-firm management controls \\
\hline \multirow[t]{2}{*}{ CRDC } & $\begin{array}{l}\text { Episode 1 } \\
2007-2009\end{array}$ & $\begin{array}{l}\text { Legislative } \\
\text { change to } \\
\text { increase Board } \\
\text { skills but } \\
\text { reduced Board } \\
\text { experience }\end{array}$ & $\begin{array}{l}\text { Inexperienced } \\
\text { decision- } \\
\text { makers }\end{array}$ & All new projects & $\begin{array}{l}\text { Switching: } \\
\text { Unable to } \\
\text { decentralise } \\
\text { investment } \\
\text { decision-making } \\
\text { function }\end{array}$ & $\begin{array}{l}\text { Regulation and contracts: } \\
\text { Legislative and } \\
\text { contractual provisions } \\
\text { about Board } \\
\text { responsibilities }\end{array}$ & & $\begin{array}{l}\text { Program } \\
\text { manager } \\
\text { evaluations; } \\
\text { Industry } \\
\text { advisory panels } \\
\text { evaluations }\end{array}$ & \\
\hline & $\begin{array}{l}\text { Episode } 3 \\
2011-2014\end{array}$ & $\begin{array}{l}\text { Funding cuts } \\
\text { concentrated } \\
\text { pool of } \\
\text { specialised } \\
\text { providers }\end{array}$ & $\begin{array}{l}\text { Mutual } \\
\text { dependence } \\
\text { on 'core' } \\
\text { providers }\end{array}$ & $\begin{array}{l}\text { Projects with } \\
\text { core researchers }\end{array}$ & $\begin{array}{l}\text { Differentiation: } \\
\text { Difficulties in } \\
\text { contracting with } \\
\text { specialised } \\
\text { providers within } \\
\text { the CRDC R\&D } \\
\text { Framework }\end{array}$ & $\begin{array}{l}\text { Control consistency: } \\
\text { Alliance R\&D funding } \\
\text { rules, stipulating } \\
\text { standardised selection } \\
\text { processes }\end{array}$ & $\begin{array}{l}\text { Contract } \\
\text { duration }\end{array}$ & $\begin{array}{l}\text { Prioritise prior } \\
\text { experience in } \\
\text { project } \\
\text { selection; } \\
\text { Streamline } \\
\text { application } \\
\text { processes }\end{array}$ & \\
\hline \multirow[t]{2}{*}{$\begin{array}{l}\text { Cotton } \\
\text { CRC }\end{array}$} & $\begin{array}{l}\text { Episode } 4 \\
2007-2011\end{array}$ & $\begin{array}{l}\text { Expansion of } \\
\text { scope to } \\
\text { continue } \\
\text { alliance } \\
\text { funding }\end{array}$ & $\begin{array}{l}\text { Contracting } \\
\text { with non- } \\
\text { partner } \\
\text { providers }\end{array}$ & $\begin{array}{l}\text { Projects in new } \\
\text { programs }\end{array}$ & $\begin{array}{l}\text { Differentiation: } \\
\text { Difficulties in } \\
\text { identifying, } \\
\text { contracting and } \\
\text { ensuring } \\
\text { compliance with } \\
\text { non-partner } \\
\text { providers }\end{array}$ & $\begin{array}{l}\text { Control consistency: } \\
\text { Standardised alliance } \\
\text { operating rules and } \\
\text { procedures; reluctance to } \\
\text { change controls used for } \\
\text { traditional programs }\end{array}$ & & $\begin{array}{l}\text { Intense } \\
\text { provider search } \\
\text { processes; } \\
\text { Direct project } \\
\text { commissioning } \\
\text { and tendering }\end{array}$ & $\begin{array}{l}\text { Employed full-time Program Leaders } \\
\text { with expertise in new programs; } \\
\text { More regular monitoring, personal } \\
\text { interaction and relationship building } \\
\text { with new providers. }\end{array}$ \\
\hline & $\begin{array}{l}\text { Episode 5 } \\
2009-2012\end{array}$ & $\begin{array}{l}\text { Unsuccessful } \\
\text { renewal bid } \\
\text { increased } \\
\text { pressure to } \\
\text { meet collective } \\
\text { targets }\end{array}$ & $\begin{array}{l}\text { Ensuring } \\
\text { contract } \\
\text { compliance }\end{array}$ & All projects & $\begin{array}{l}\text { Switching: } \\
\text { Unable to alter } \\
\text { alliance } \\
\text { objectives or } \\
\text { extend life or } \\
\text { change to a } \\
\text { perpetual } \\
\text { arrangement }\end{array}$ & $\begin{array}{l}\text { Regulation and contracts: } \\
\text { CRC Program rules and } \\
\text { Partnership Agreement } \\
\text { specifying the deliverables } \\
\text { and limited life of the } \\
\text { CRC }\end{array}$ & & & $\begin{array}{l}\text { Hire executive to implement centre- } \\
\text { wide monitoring and evaluation } \\
\text { program; } \\
\text { Frequent manager meetings, project } \\
\text { monitoring and project intervention } \\
\text { strategies; } \\
\text { 'Fail fast' culture. }\end{array}$ \\
\hline
\end{tabular}

